\title{
Hydrodynamics of a channel occupied by the aquaculture industry in southern Chile: implications for connectivity between farms
}

\author{
Marcus Sobarzo ${ }^{1,2, *}$, Luis Bravo ${ }^{3,4}$, Claudio Iturra ${ }^{5}$, Alfredo Troncoso $^{1}$, \\ Roberto Riquelme $^{6}$, Patricio Campos $^{7}$, Cristian Agurto ${ }^{8}$
}

\author{
${ }^{1}$ Departamento de Oceanografía, Facultad de Ciencias Naturales y Oceanográficas, Universidad de Concepción, \\ 4030000 Concepción, Chile \\ ${ }^{2}$ Centro Interdisciplinario para la Investigación Acuícola (INCAR), 4030000 Concepción, Chile \\ ${ }^{3}$ Departamento de Biología Marina, Facultad de Ciencias del Mar, Universidad Católica del Norte, 1780000 Coquimbo, Chile \\ ${ }^{4}$ Núcleo Milenio en Ecología y Manejo Sustentable de Islas Oceánicas (ESMOI), Universidad Católica del Norte, \\ 1780000 Coquimbo, Chile \\ ${ }^{5}$ Programa de Postgrado en Oceanografía, Departamento de Oceanografía, Facultad de Ciencias Naturales y Oceanográficas, \\ Universidad de Concepción, 4030000 Concepción, Chile \\ ${ }^{6}$ Departamento de Ingeniería Matemática, Facultad de Ciencias Físicas y Matemáticas, Universidad de Concepción, \\ 4030000 Concepción, Chile \\ ${ }^{7}$ Instituto de Ciencias y Tecnología, Universidad Arturo Prat, 5480000 Puerto Montt, Chile \\ ${ }^{8}$ Centro de Biotecnología, Universidad de Concepción, 4030000 Concepción, Chile
}

\begin{abstract}
Residual circulation from nonlinear interaction of the tidal currents with topography in channels, fjords and bays can be important to represent the distance traveled by suspended materials in the water column (e.g. pathogens). Here the role of the semidiurnal tidal excursion was compared with residual currents, during autumn 2011, to evaluate the connectivity among aquaculture production centers in Caucahue Channel (Chiloe Island, southern Chile), which has been widely occupied by the aquaculture industry. During 2015, around $30000 \mathrm{t}$ of 3 different species of salmon were harvested in this channel, representing $3.7 \%$ of the national production. Along- and cross-channel tidal currents explained around 80 and $40-60 \%$ of the total variance, respectively. Thus, the major residual circulation came from the cross-channel component (40-60\% of the total variance) caused by tidal asymmetry. We hypothesized that this asymmetry is related to the nonlinear interaction of the oscillatory flow with the Quemchi constriction. The residual advective distances $\left(L_{\text {adv }}\right)$ were compared with tidal excursion $\left(L_{\text {exc }}\right)$ and biological diffusivity $\left(L_{\text {diff }}\right)$ scales, considering the distances between centers $\left(L_{\text {int }}\right)$, the size of the centers $\left(L_{\text {cen }}\right)$ and the length of the south arm of the Cauchaue Channel $(L=11 \mathrm{~km})$. For $3 \mathrm{~d}$ time scales, the $L_{\text {adv }} / L_{\text {exc }}$ ratio fluctuated between 1.3 and 8, approximately, implying that, although the advective scale is greater, the tidal flow is still intense enough to favor the retention of pathogens. For larger time scales that consider longer-lived pathogens (e.g. greater than $15 \mathrm{~d}$ ), this ratio grows 1 order of magnitude. In this scenario and in the event of an outbreak within the channel, pathogens could be exported.
\end{abstract}

KEY WORDS: Tidal excursion · Long-term residual advection · Tidal asymmetry · Chilean aquaculture industry $\cdot$ Waterborne pathogens

\section{INTRODUCTION}

The Chiloe Inland Sea (CIS), located on the west side of the Southern Cone of South America, extends from Puerto Montt $\left(41^{\circ} 30^{\prime} \mathrm{S}\right)$ to the mouth of Guafo $\left(43^{\circ} 40^{\prime} \mathrm{S}\right)$ along ca. $260 \mathrm{~km}$, and includes a series of fjords and channels, some of which have been widely

*Corresponding author: msobarz@udec.cl occupied by the aquaculture industry since around 1915-1930 (Rudolph et al. 2010, Bustos 2012) (see boxes in Fig. 1). The subsequent increase of aquaculture farms in this area has introduced strong environmental pressures on the carrying capacity of these semi-enclosed systems, which sustain the industry (Buschmann et al. 2001, 2006). In 2006, Chile pro- 
duced 647000 t of salmonids, which in 2009 dropped by approximately $20 \%$ due to the spread of infectious salmon anemia virus (ISAV) in southern Chile (Godoy et al. 2008). In 2011, production was recovered to levels above 2007, and in 2012, production increased to $827203 \mathrm{t}$ (Sernapesca 2012).

Although the Chilean Government reacted to ISAV outbreaks by taking steps to manage the sanitary crisis (e.g. creating aquaculture neighborhoods and increased biosecurity measures), it is now known that the dynamics of water in the channels and fjords of the CIS can potentially have a greater influence on waterborne pathogens than previously thought (Buschmann et al. 2009, 2013). For example, in the Quoddy region of Maine (USA) and New Brunswick (Canada), where Atlantic salmon farms are closely spaced (0.5-4.2 km) (Gustafson et al. 2007), extremely large tidal currents (Brooks 2004) can drive the exchange of water, and potentially waterborne pathogens, reaching up to 7 farms within a single tidal cycle (Chang et al. 2005a). Research on ISAV outbreaks in Chile (Mardones et al. 2011) and Norway (Lyngstad et al. 2008) agree that the onset of the disease is slow and then spreads with epidemic behavior around the initial outbreak. Clustering of cases supports the assumption that passive transmission in seawater from ISAV-infected farms (proximity) is a critical factor in controlling the disease (Mardones et al. 2009). In this context, the connectivity mechanisms provided by the local hydrodynamics (tidal excursion and residual currents) are fundamental to better understand the distances of dispersion and advection (Largier 2003).

In the case of the CIS, despite the intensive use of its channels by the aquaculture industry, understanding of the hydrodynamics of these inner channels is still limited. The hydrodynamics of some geographical areas have been studied in this region (see Fig. 1), including the Reloncaví Fjord (Castillo et al. 2012, Valle-Levinson et al. 2014), Chacao Channel (Cáceres et al. 2003) and others (Aiken 2008, Cáceres et al. 2008, Marín \& Campuzano 2008, Salinas \& Castillo 2012), but the connectivity among aquaculture centers based on tidal excursion and/or residual currents was not considered.

Unlike the fjords on the east side of CIS, where gravitational circulation driven by rivers is important, the coastal area adjacent to Chiloe Island (located on the west side of the CIS) has no major continental water inputs, and thus wind, tides and topography can be expected to be the main forcings modulating the hydrodynamics. In this context, our research sought to clarify the role of tidal and residual currents on the retention and transport of materials in the water column in a typical channel of the CIS. The study was not intended to describe the non-tidal circulation pattern inside of Caucahue Channel or to evaluate the Lagrangian transport within it. Instead, we aimed to compare the advective residual scales with tidal excursion and biological diffusivity scales to then apply them to the typical scales of the locations of aquaculture production centers in 1 channel of southern Chile.

\section{MATERIALS AND METHODS}

\section{Study area}

The Caucahue Channel is located in the northeastern sector of Chiloe Island $\left(42^{\circ} 08^{\prime} 30^{\prime \prime} \mathrm{S}, 73^{\circ}\right.$ $28^{\prime} 00^{\prime \prime} \mathrm{W}$ ), on the western edge of the Gulf of Ancud and just $32 \mathrm{~km}$ from the mouth of the Chacao Channel $\left(41^{\circ} 47^{\prime} 00^{\prime \prime} \mathrm{S}, 73^{\circ} 35^{\prime} 00^{\prime \prime} \mathrm{W}\right), 1$ of the 2 connections between CIS and the Pacific Ocean (Fig. 1). The other connection, the Guafo mouth, is located approximately $165 \mathrm{~km}$ to the south, and is considerably wider and deeper than the Chacao Channel. It is recognized as the main connection to the Pacific Ocean, where the propagating tidal waves enter the CIS (Aiken 2008). The distance between Puerto Montt $\left(41^{\circ} 28^{\prime} 20^{\prime \prime} \mathrm{S}, 72^{\circ} 56^{\prime} 00^{\prime \prime} \mathrm{W}\right)$, the northern limit of the CIS, and the Guafo mouth, the southern limit, is approximately $260 \mathrm{~km}$ (Fig. 1).

The Caucahue Channel separates Caucahue Island from Chiloe Island, forming a channel with 2 arms connected to the CIS through the northern and southern mouths. These mouths have maximum depths close to $120 \mathrm{~m}$, and widths ranging from $3.8 \mathrm{~km}$ (northern entrance) to $2.9 \mathrm{~km}$ (southern entrance). The northern and southern arms extend over 7.5 and $11.0 \mathrm{~km}$, respectively, with maximum depths close to both mouths. Both arms are connected in Quemchi, the narrowest $(0.8 \mathrm{~km})$ and the shallowest $(<40 \mathrm{~m})$ place in this channel (hereafter referred to as the Quemchi constriction). Therefore, this channel has 3 topographic features that can modify the oscillatory tidal flow: (1) it is a curved channel; (2) the channel is shallow in its central part, changing from depths of around $100 \mathrm{~m}$ in its 2 mouths, to less than $40 \mathrm{~m}$ in the Quemchi constriction; and (3) the cross-sectional area of this constriction $\left(0.017 \mathrm{~km}^{2}\right)$ is reduced by 10 to 20 times, approximately, compared to the southern mouth $\left(0.21 \mathrm{~km}^{2}\right)$ and the northern mouth $\left(0.38 \mathrm{~km}^{2}\right)$, respectively (Fig. 1).

On the other hand, the Caucahue Channel hosts 13 concessions for salmon farming that include Atlantic salmon Salmo salar, Pacific (coho) salmon Onco- 
rhynchus kisutch and rainbow trout $O$. mykiss. In 2015, around $30000 \mathrm{t}$ were obtained, which represented $7.8 \%$ of regional production and $3.7 \%$ of national production (Sernapesca 2015). In addition to the cultivation of salmon, 38 concessions for shellfish and 6 concessions for the cultivation of seaweed operate in this channel (see boxes in Fig. 1, indicating production centers). The size of the production centers $\left(L_{\mathrm{cen}}\right)$ fluctuated between 0.1 and $0.3 \mathrm{~km}$. The distance between them $\left(L_{\text {int }}\right)$ varied from 1 to $5 \mathrm{~km}$, if only the salmon farming centers are included, or less, if all the production centers are considered. According to Mardones et al. (2011), during the ISAV epidemic in southern Chile in 2007-2009, only the south arm of this channel was infected.

\section{Observations and analyses}

Measurements of currents were made using an RDI Workhorse $300 \mathrm{kHz}$ acoustic Doppler current profiler (ADCP) deployed between 17 April and 21 July 2011 in the southern arm of the Caucahue Channel at a site with $55 \mathrm{~m}$ depth. The ADCP was installed at about $50 \mathrm{~m}$ depth, with transducers facing upwards, within a frame of fiberglass anchored at $4 \mathrm{~m}$ to the bottom. This instrument recorded data every $15 \mathrm{~min}$ with a vertical resolution of $2 \mathrm{~m}$, with valid data between 4 and $46 \mathrm{~m}$ depth. A tide gauge (SBE 26 SEAGAGE; wave and tide recorder), installed simultaneously near the southern mouth $\left(42^{\circ} 12^{\prime} 36^{\prime \prime} \mathrm{S}, 73^{\circ} 23^{\prime}\right.$ $10^{\prime \prime} \mathrm{W}$ ), was programmed to measure with the same frequency. This study was authorized by the Hydrographic and Oceanographic Service of the Chilean Navy as stated in Decree No. 13279/24/234 (11 April 2011).

Prior to the analysis of the current time series, hourly mean values were calculated and were referred to the geographic North, considering the magnetic declination for the study area $\left(9.6^{\circ} \mathrm{E}\right)$. Due to the orientation of the coastline and the 25 and $50 \mathrm{~m}$ isobaths at the ADCP deployment site, currents were decomposed into their along- and cross-channel axes (Fig. 1). The new rotated axes were oriented with the $y$-axis toward $10^{\circ} \mathrm{N}$ (cross-channel); and the $x$-axis towards $100^{\circ} \mathrm{N}$ (along-channel), which was the major axis. Cross- and along-channel currents were designated by $v$ and $u$, respectively, with $u$ positive to the east (out of the channel).

The contributions of the principal constituents of tides for currents and sea level were determined using harmonic analysis (Pawlowicz et al. 2002). Residual currents were calculated by subtracting tidal currents estimated from significant tidal constituents from the total current. This residual current was filtered using a $30 \mathrm{~h}$ Lanczos cosine filter in order to extract high-frequency fluctuations present in the 
residuals. All analyses were repeated with the original time series every $15 \mathrm{~min}$. No significant variations were found between both analyses, so all data and graphs shown were made using hourly values.

After the harmonic analysis and considering the predominance of the semidiurnal constituents, a bandpass filter was used with cut-off frequencies of 0.1 to 0.071 cycles $\mathrm{h}^{-1}$ (10 to $14 \mathrm{~h})$. This band incorporates M2, S2, N2 and K2 semidiurnal constituents. This filter was used for the study of the coherence and crosscorrelation between currents and sea level.

The above observations were complemented by hydrographical data collected along the main axis of the channel and using 10 stations on 17-19 April 2011 (Fig. 1). Temperature, conductivity, pressure and dissolved oxygen were measured using a Sea Bird CTDO at all of these stations. The stratification of the water column was calculated using the Brunt-Väisälä (or buoyancy) frequency $N$ (in cycles $\mathrm{h}^{-1}$ ). This is defined as $N / 2 \pi=$ $(g E)^{1 / 2} / 2 \pi$, where $E=-(1 / \rho)\left(\partial \sigma_{t} / \partial z\right), g$ is the acceleration of gravity, $\rho$ is density, $\sigma_{t}$ is sigma- $t$, and $z$ is the depth, considered negative towards the bottom (Pond \& Pickard 1983).

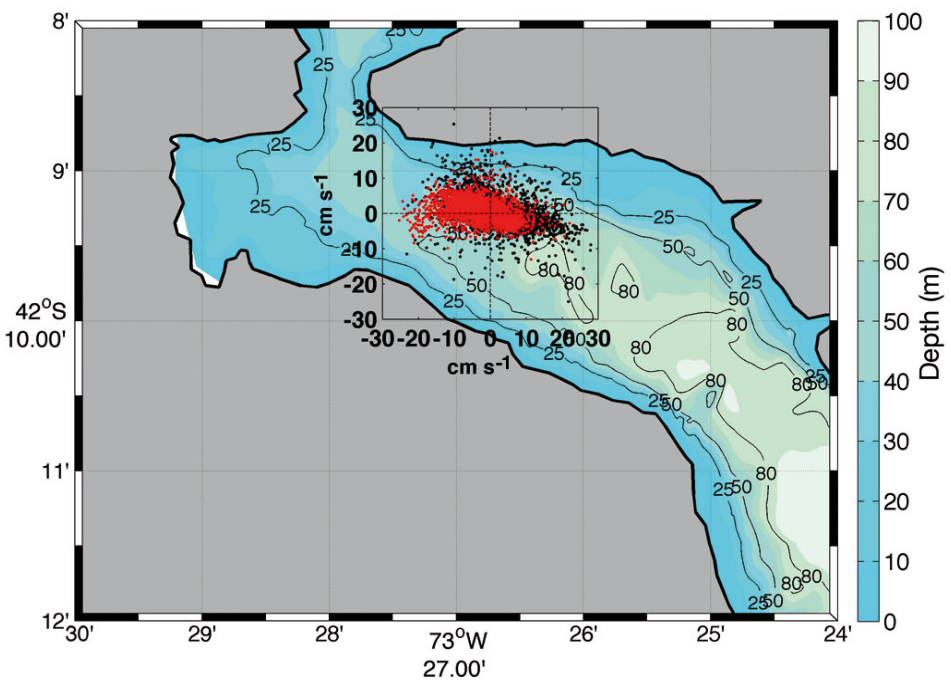

Fig. 2. Surface (black dots) and bottom (red dots) scatter plots of the total current in Caucahue Channel, 17 April to 21 July 2011

\section{RESULTS}

\section{Mean flow and variability of the total current}

Consistent with the local bathymetry, the dispersion of the total current tended to be elliptical, with its major axis oriented approximately along the chan-

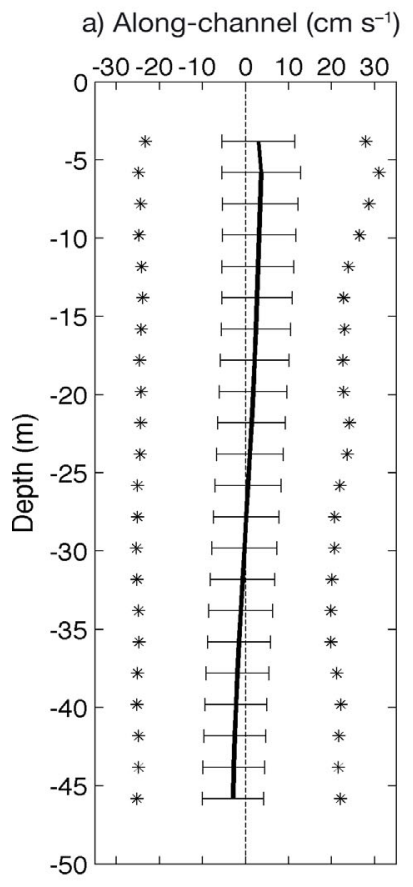

b) Cross-channel $\left(\mathrm{cm} \mathrm{s}^{-1}\right)$

c) Variance $\left(\mathrm{cm}^{2} \mathrm{~s}^{-2}\right)$

d) Maximum variance (\%)
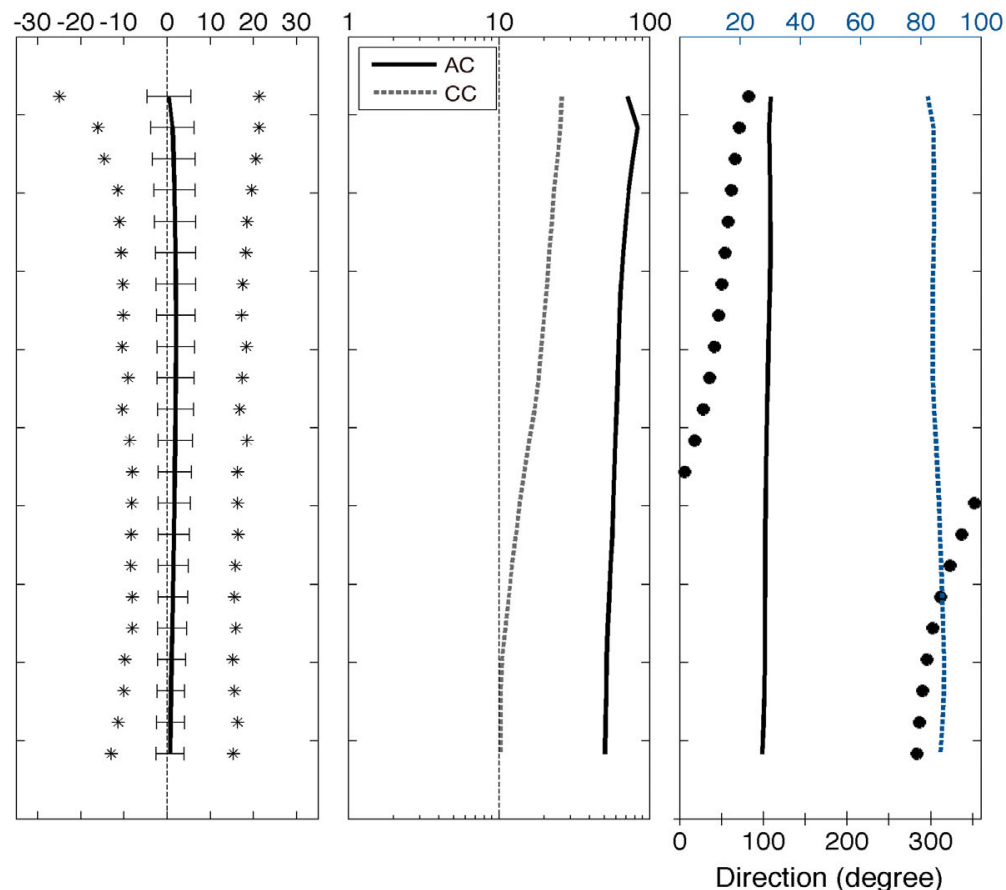

Fig. 3. (a,b) Mean vertical structure (continuous black line), standard deviation (error bars) and maximum and minimum values (*) of the total current in the along- (AC) and cross-channel (CC) axes, respectively. (c) Variance in both components. (d) Mean flow direction (black dots), percentage of explained variance by major principal axis (MPA, i.e. the maximum variance of the total current; blue line) and orientation of the MPA (black line). Caucahue Channel, 17 April to 21 July 2011 
nel, and with total surface currents trending eastward (black points) and bottom currents trending westward (red points), with values that did not exceed $30 \mathrm{~cm} \mathrm{~s}^{-1}$ (Fig. 2). Within the first $24 \mathrm{~m}$ depth, currents along the channel showed an eastward tendency (positive); below $34 \mathrm{~m}$ there was a westward predominant flow (negative), with mean values, in both cases, below $3 \mathrm{~cm} \mathrm{~s}^{-1}$ (Fig. 3a). The maximum values along the channel and throughout the water column ranged from -28 to $30 \mathrm{~cm} \mathrm{~s}^{-1}$, approximately. Across the channel (approximately north-south direction), maximum values were lower, showing a mean flow northward within the first $35 \mathrm{~m}$ depth (Fig. 3b). The variance of the total currents was greater along the channel than across the channel, showing a gradual reduction of the kinetic energy with depth, especially in the cross-channel component (Fig. 3c).

The major principal axis or maximum variance of the total current at each level explained about $80 \%$ of the flow variability and was virtually constant throughout the entire water column. The orientation of this axis also remained constant throughout the water column (about $100^{\circ}$ ) and aligned with the axis of the channel (Fig. 3d). Meanwhile, the mean flow direction showed a counterclockwise rotation with depth from $\sim 60^{\circ}$ (surface) to $\sim 280^{\circ}$ (at $47 \mathrm{~m}$ depth) (Fig. 3d). A summary with the descriptive statistics of the total and subtidal currents is provided in Table 1.

\section{Harmonic analysis of sea levels and tidal currents}

Harmonic decomposition of the sea level measured from a tide gauge (see Fig. 1) showed the predominance in amplitude of 3 semidiurnal constituents
(M2, S2 and N2) over diurnal and shallow-water constituents (K1, O1, M4 and others). The percentage of the total variance explained by M2, S2, N2, K1 and O1 was $82.8,7.1,4.4,1.9$ and $0.7 \%$, respectively. Thus, the explained variance by predicted sea level, using all significant constituents, was $99 \%$ and $\mathrm{F}=$ $(\mathrm{K} 1+\mathrm{O} 1) /(\mathrm{M} 2+\mathrm{S} 2)$ was equal to 0.18 . This value indicates that the predominant tidal regime within this channel was semidiurnal. The phase of the main semidiurnal constituents M2, N2 and S2 was of $64.2^{\circ}$, $78.8^{\circ}$ and $30.7^{\circ}$, respectively.

The harmonic analysis of the total current revealed that significant constituents (including semidiurnals, diurnals and shallow-water constituents) explained about $80 \%$ of the along-channel current variability, except within the first $15 \mathrm{~m}$ depth, where the percentage was slightly lower (solid red line in Fig. 4a). In contrast, in the cross-channel component, the variance explained by the significant constituents fluctuated only between 40 and $60 \%$. Of these significant constituents, the one of greater amplitude was M2, reaching an average of $8 \mathrm{~cm} \mathrm{~s}^{-1}$ (range $7-9 \mathrm{~cm} \mathrm{~s}^{-1}$ ) for the entire water column. S2 reached amplitudes between 2 and $3.5 \mathrm{~cm} \mathrm{~s}^{-1}$, and $\mathrm{N} 2$ was below $2.5 \mathrm{~cm} \mathrm{~s}^{-1}$ (not shown). Along-channel detided currents explained about $20 \%$ below $15 \mathrm{~m}$ depth (Fig. 4a) and near $36 \%$ in the surface $5 \mathrm{~m}$. On the other hand, the explained variance of the cross-channel detided currents fluctuated between 44 and $63 \%$. Amplitudes of $\mathrm{K} 1, \mathrm{O} 1$ and M4 were much less energetic and did not exceed $1 \mathrm{~cm} \mathrm{~s}^{-1}$ throughout the water column. Virtually all constituents showed changes in their phases near the bottom (Fig. 4b). M2 showed elliptical orbits with the major axis oriented along the channel and with amplitudes close to $8 \mathrm{~cm} \mathrm{~s}^{-1}$ throughout the

Table 1. Statistics of total and subtidal currents in Caucahue Channel during the period between 17 April and 21 July 2011. $u_{\text {mean }}$ and $v_{\text {mean }}\left(u_{\mathrm{SD}}\right.$ and $v_{\mathrm{SD}}$ ) are the mean flow (standard deviation) of the along and cross-channel currents, respectively. $K_{\mathrm{E}}$ is the kinetic energy. The orientation of the major principal axis (MPA) and mean flow (magnitude in $\mathrm{cm} \mathrm{s}^{-1} /$ direction in degrees) are defined with respect to the geographical north

\begin{tabular}{|ccccccccc|}
\hline & Depth $(\mathrm{m})$ & $u_{\text {mean }}\left(\mathrm{cm} \mathrm{s}^{-1}\right)$ & $v_{\text {mean }}\left(\mathrm{cm} \mathrm{s}^{-1}\right)$ & $u_{\mathrm{SD}}\left(\mathrm{cm} \mathrm{s}^{-1}\right)$ & $v_{\mathrm{SD}}\left(\mathrm{cm} \mathrm{s}^{-1}\right)$ & $K_{\mathrm{E}}\left(\mathrm{cm} \mathrm{s}^{-1}\right)^{2}$ & MPA & Mean flow \\
\hline Total & 4 & 2.9 & 0.9 & 8.7 & 4.6 & 4.6 & 109 & $3.0 / 72^{\circ}$ \\
currents & 12 & 2.3 & 2.4 & 8.4 & 4.1 & 5.4 & 108 & $3.3 / 44^{\circ}$ \\
& 24 & 0.3 & 1.9 & 7.9 & 3.6 & 1.9 & 103 & $1.9 / 8^{\circ}$ \\
& 36 & -2.0 & 0.8 & 7.4 & 3.0 & 2.4 & 101 & $2.2 / 292^{\circ}$ \\
Subtidal & 46 & -3.0 & 0.2 & 7.2 & 3.1 & 4.3 & 98 & $3.0 / 273^{\circ}$ \\
currents & 4 & 3.0 & 0.9 & 3.5 & 1.8 & 4.8 & 103 & $3.1 / 73^{\circ}$ \\
& 12 & 2.4 & 2.3 & 2.1 & 1.4 & 5.6 & 105 & $3.4 / 46^{\circ}$ \\
& 24 & 0.4 & 1.9 & 1.8 & 1.2 & 1.9 & 86 & $1.9 / 13^{\circ}$ \\
& 36 & -1.8 & 0.8 & 1.8 & 1.1 & 2.0 & 79 & $2.0 / 294^{\circ}$ \\
& 46 & 2.6 & 0.2 & 1.8 & 1.1 & 3.8 & 83 & $2.7 / 275^{\circ}$ \\
\hline
\end{tabular}



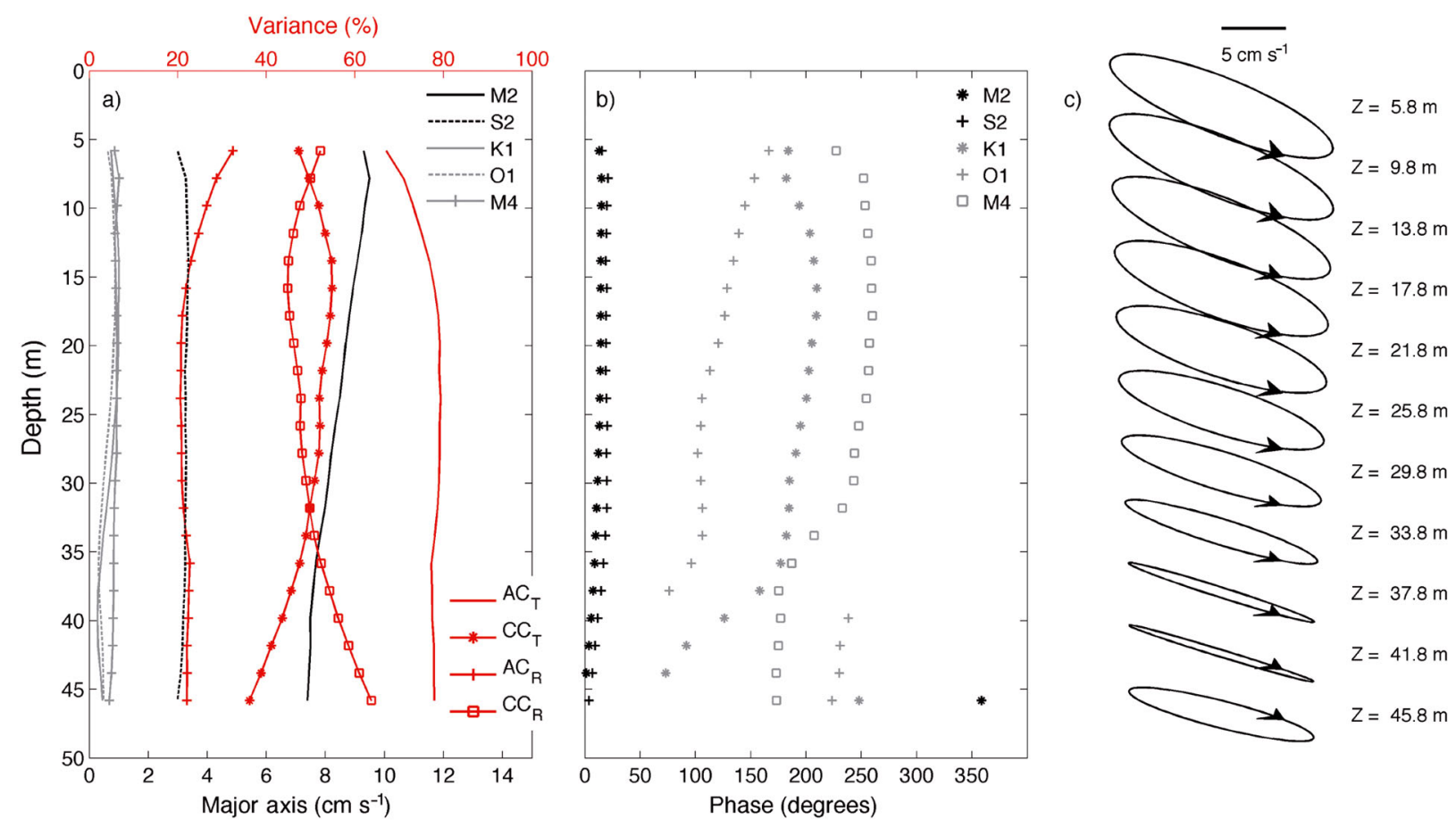

Fig. 4. (a) Vertical structure of the percentage of variance explained (red lines) by tidal along- and cross-channel currents $\left(\mathrm{AC}_{\mathrm{T}}\right.$ and $\mathrm{CC}_{\mathrm{T}}$, respectively) and detided along- and cross-channel currents $\left(\mathrm{AC}_{\mathrm{R}}\right.$ and $\mathrm{CC}_{\mathrm{R}}$, respectively), and of the amplitudes of the main tidal constituents (M2, S2, K1,O1, M4; black and grey lines). (b) Vertical structure of the phase of the main tidal constituents. (c) Semidiurnal tidal ellipses for M2. Caucahue Channel, 17 April to 21 July 2011

water column. This constituent rotated counterclockwise, with the exception of the bottom layers (41.8 to $45.8 \mathrm{~m}$ ) (Fig. 4c).

In order to link current meter data coming from the ADCP with the sea level measured by the tide gauge (both instruments located about $8 \mathrm{~km}$ away, Fig. 1), the phase difference between both instruments was calculated through the cross-correlation analysis between original series (both series sampled every $15 \mathrm{~min}$ ) of sea level and the surface backscatter recorded by the ADCP. The correlation was maximum at 0 lag $(r=0.8)$, and therefore it was assumed that tidal phase was the same in both instruments. This is consistent with a tidal wave that will travel as a shallow water wave in an unstratified channel at a speed given by $c=(g h)^{1 / 2}$. Considering $h($ depth $)=$ $50 \mathrm{~m}$ for Caucahue Channel and $g$ (acceleration due to gravity) $=9.8 \mathrm{~m} \mathrm{~s}^{-2}$, the tidal wave travels with $c=$ $93.5 \mathrm{~km} \mathrm{~h}^{-1}$. With this speed, the time it takes the wave to travel from the tide gauge to the ADCP is only $5 \mathrm{~min}$.

Considering the predominance of the semidiurnal constituents, a bandpass filter was applied to the sea level and tidal currents to separate the semidiurnal band located between 10 and $14 \mathrm{~h}$. With these filtered time series, the relationship between sea level and tidal currents in the semidiurnal band was ex- plored. Progressive tides have maximum current speeds at high and low tides (in opposite directions). When the progressive tide meets a reflection, a standing wave can arise. When this happens, the strongest tidal currents occur when sea level is near its mean value. For example, using a typical day of spring tides, major eastward and westward semidiurnal tidal currents at 5.8 and $45.8 \mathrm{~m}$ depth occurred during ebb and flood tides, respectively (Fig. 5a,b), which is approximately consistent with a standing wave. However, the higher speed showed a delay of about $1 \mathrm{~h}$ from the mean sea level. During neap tides, the maximum values of currents showed a delay of 1 to $2 \mathrm{~h}$ in relation to the mean sea level (Fig. 5c,d).

To expand this analysis to both components (along and cross-channel), cross-spectral and crosscorrelation analyses were performed between semidiurnal currents and sea level (Fig. 6). Using the complete time series, the coherence between sea level and along-channel tidal currents (AC) at each level of depth was close to 0.96 , and the phase varied between 4 and $5 \mathrm{~h}$ (considering the peaks in sea level and tidal currents). On the other hand, the coherence between sea level and the cross-channel tidal currents (CC) fluctuated between 0.93 (surface) and 0.65 (bottom). The phase was between 3 and $4 \mathrm{~h}$ in the first $30 \mathrm{~m}$ depth. Below this depth the phase de- 

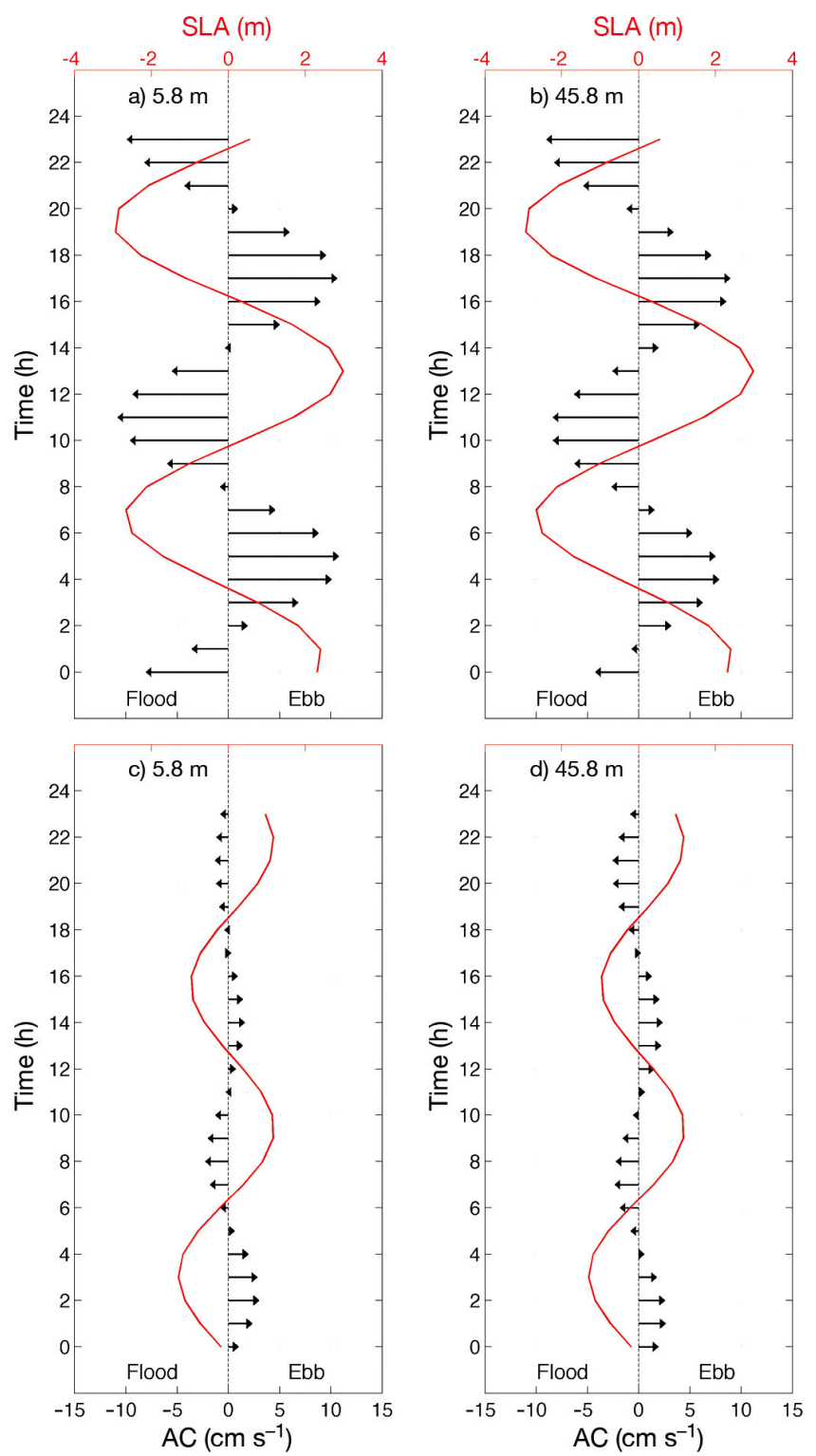

Fig. 5. Semidiurnal sea level anomalies (SLA, solid red line) and semidiurnal along-channel (AC) tidal currents (black arrows). During spring tides (16 May 2011): (a) surface and (b) bottom. During neap tides (26 May 2011): (c) surface and (d) bottom

creased to $0 \mathrm{~h}$ near the bottom (Fig. 6a,b). That is, the tidal wave was close to a standing wave. Crosscorrelation between sea level and along-channel tidal currents (AC) at each level of depth during the 6 periods of spring tides was around 0.91-0.97 with a lag of 4 and 5 h (Fig. 6c,d). During neap tides, crosscorrelation was around 0.90-0.96 and the lag for all neap tide events was $3 \mathrm{~h}$ (Fig. 6f). Separate analyses for spring and neap tides in the cross-channel axis did not show marked differences in the cross-correlation (not shown). In this way, the tidal wave behaves like a standing wave during neap tides, changing its phase from 1 to $2 \mathrm{~h}$ during spring tides, probably due to the intensifications of tidal currents.

\section{Role of tidal excursion and residual currents in the retention and advection of water out of the channel}

The above analyses showed the predominance of the barotropic semidiurnal tidal currents of the Caucahue Channel and fortnightly tidal changes that affected the vertical structure of the water column. In this section we compare the advective length scales ( $\left.L_{\text {adv }}\right)$ associated with the residual current with the tidal excursion length scales $\left(L_{\text {exc }}\right)$. While the advective distances are more related to the export of suspended materials from one place to another, the tidal excursions contribute directly to retention processes. First notice that temporal changes in the observed sea level (semidiurnal and spring-neap tides) (Fig. 7a), were related to the increase and decrease of the along-channel total current (Fig. 7b). As we have already noted, flood and ebb cycles were accompanied by westward (negative) and eastward (positive) currents, respectively (Fig. 5). On the other hand, the total cross-channel current showed a predominant northward flow (Fig. 7c).

The along-channel residual circulation showed 2 layers with variable thickness: (1) an eastward surface layer (south mouth of the Caucahue Channel), (2) a bottom layer with westward currents (Quemchi town, Fig. 7e). The cross-channel residual circulation showed persistent northward currents at surface and mid-waters and southward currents near to the bottom (Fig. 7f). Although the wind measured in Quemchi showed an eastward direction (positive values), it was of low intensity $\left(<5 \mathrm{~m} \mathrm{~s}^{-1}\right)$ and without an apparent relationship with the residual surface circulation (Fig. 7d). Similarly, the northward residual trend in the cross-channel component was not correlated with the cross-channel wind.

The advective length scales were evaluated by means of comparative progressive vector diagrams and using $3 \mathrm{~d}$ during each of the neap (Table 2) and spring tides (Table 3). In each table, the start date of the neap or spring tides is shown (month/day) and the distance $(\mathrm{km})$, speed $\left(\mathrm{km} \mathrm{d}^{-1}\right)$, direction (referred to the geographical north) and the stability (constancy) of the total and residual currents for 3 levels of depth (surface, mid-water and bottom) are indicated. As an example, the spring tide of 2 June and neap tide of 25 May are shown in Fig. 8. Residual and total currents showed the 2 layers of circulation 


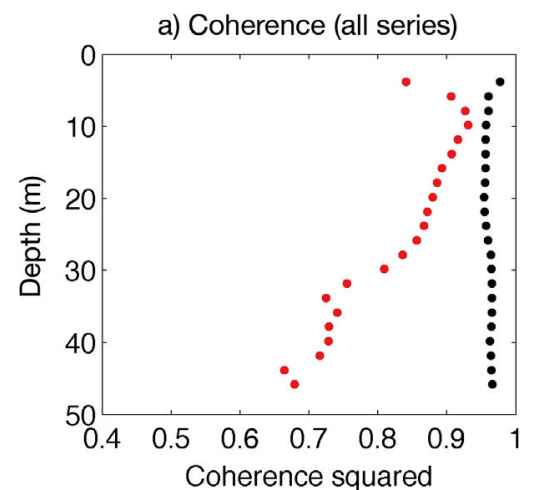

c) Cross-correlation (Spring)
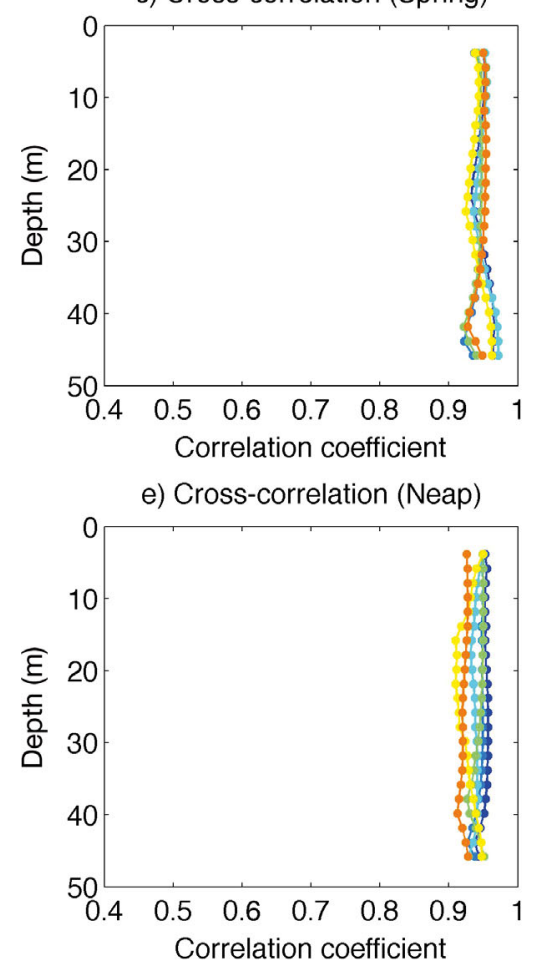

e) Cross-correlation (Neap) b) Phase (all series)

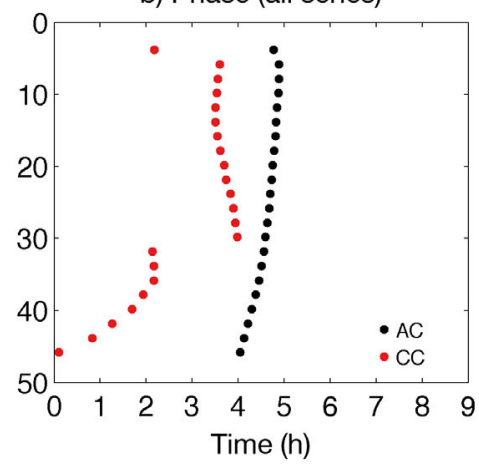

d) Lag (Spring)

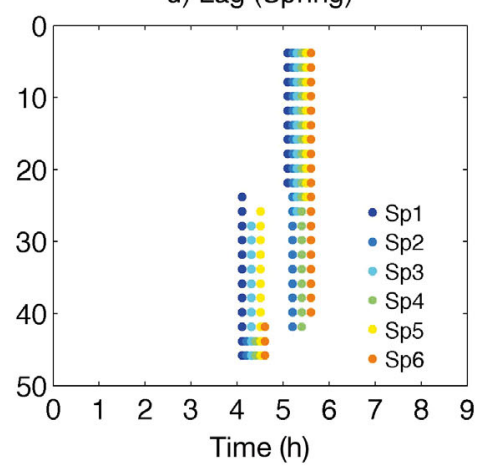

f) Lag (Neap)

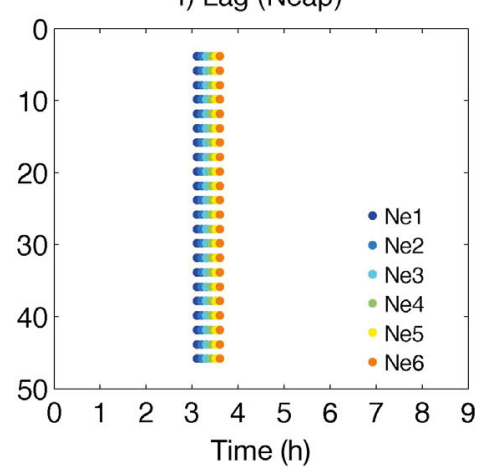

Fig. 6. Statistical relationships between sea level and semidiurnal currents. $(\mathrm{a}, \mathrm{b})$ Analysis of coherence and phase using the complete time series for both components (AC: along-channel; CC: cross-channel). (c,d) Along-channel crosscorrelation analysis during spring tides. (e,f) Along-channel cross-correlation analysis during neap tides. Sp1 to Sp6: chronologically, the 6 spring tides of the series. Ne1 to Ne6: chronologically, the 6 neap tides of the series

fluctuated between 1.8 and $3.2 \mathrm{~km} \mathrm{~d}^{-1}$ (Tables 2 \& 3). Using the definition from Largier (2003), this implies that the advective length scales reached values of $L_{\mathrm{adv}}=5.4$ to $9.6 \mathrm{~km}$, with $L_{\mathrm{adv}} \approx u T_{\mathrm{adv}}$ where $u$ is the residual velocity. Here, $T_{\text {adv }}$ is an approximation to the duration of spring or neap tides ( $3 \mathrm{~d}$ ). Three days is a good approximation of $T_{\mathrm{adv}}$ because the hydrodynamic conditions in the channel change with the springneap tidal cycle. Considering that the southern arm of the Caucahue Channel is ca. $11 \mathrm{~km}$ long and $2.5 \mathrm{~km}$ wide, the longest surface $L_{\text {adv }}$ values are comparable to the scale of this basin.

On the other hand, the tidal excursion estimated from progressive vector diagrams of the tidal currents showed distances slightly greater than $2 \mathrm{~km}$ during spring tides, and around $1 \mathrm{~km}$ during neap tides (Fig. 8c,f). Using the definitions of Valle-Levinson (2013), the tidal excursion length scales alongchannel $\left(D_{X}\right)$ and cross-channel $\left(D_{Y}\right)$ were defined as: $D_{X}=U_{o} T_{\mathrm{M} 2} / \pi$ and $D_{Y}=V_{o} T_{\mathrm{M} 2} / \pi$, where $T_{\mathrm{M} 2}$ is the semidiurnal tidal period in seconds (44712 s) and $U_{o}$ and $V_{o}$ are the maximum alongand cross-basin current, respectively. Using these equations, maximum semidiurnal tidal excursion ellipses for the case of Caucahue Channel were calculated. Considering maximum values of $U_{o}$ between 12 and $15 \mathrm{~cm} \mathrm{~s}^{-1}, D_{x}$ fluctuated between 2.4 and $4.0 \mathrm{~km}$, being greater in the surface layer (blue ellipses in Fig. 9). Because this maximum excursion is typical of the spring tides, the percentage of occurrence is rather low, i.e. less than $3.0 \%$ of the entire record.

already mentioned in the previous section. In $3 \mathrm{~d}$, the surface residual current reached $11 \mathrm{~km}$ towards the east during spring tides (Fig. 8b). During neap tide of 25 May, the surface distance was smaller $(8.4 \mathrm{~km})$ and towards the north $\left(35^{\circ}\right)$ (Fig. 8e). The bottom layer penetrated about $9 \mathrm{~km}$ westward $\left(278^{\circ}\right)$ during spring tides and also changed direction towards the north during neap tides. On average, the residual velocities were slightly lower during spring tides and more intense in the surface layer, varying between 1.9 and $2.6 \mathrm{~km} \mathrm{~d}^{-1}$. Mean velocities during neap tides
During spring tides, the mean tidal excursion was more elliptical at the bottom and decreased to values close to $2 \mathrm{~km}$ (black ellipses in Fig. 9). Considering typical mean velocities for spring tides, this mean excursion represented approximately $30 \%$ of the entire record. During neap tides, along-channel excursion reached near 1.2-1.8 $\mathrm{km}$ (red ellipses in Fig. 9). Therefore, considering the spring-neap cycle, $L_{\text {exc }}$ fluctuated between 1.2 and $4 \mathrm{~km}$. The greatest excursions are observed in the surface layer and during the greater tidal ranges. 


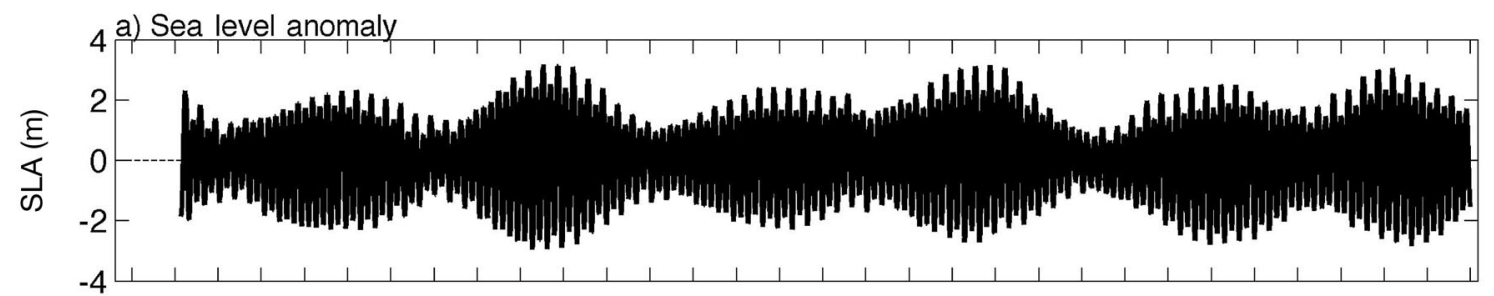

0 b) Along-channel total component

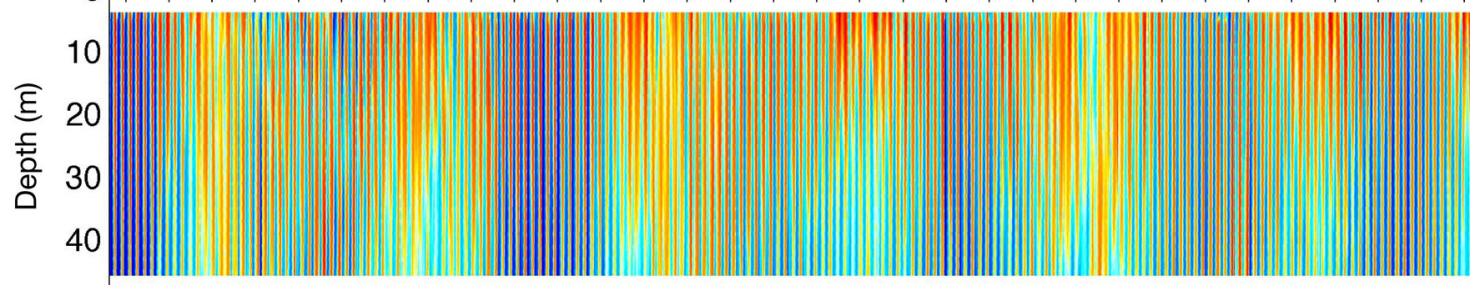

Velocity $\left(\mathrm{cm} \mathrm{s}^{-1}\right)$

50

0 C) Cross-channel total component
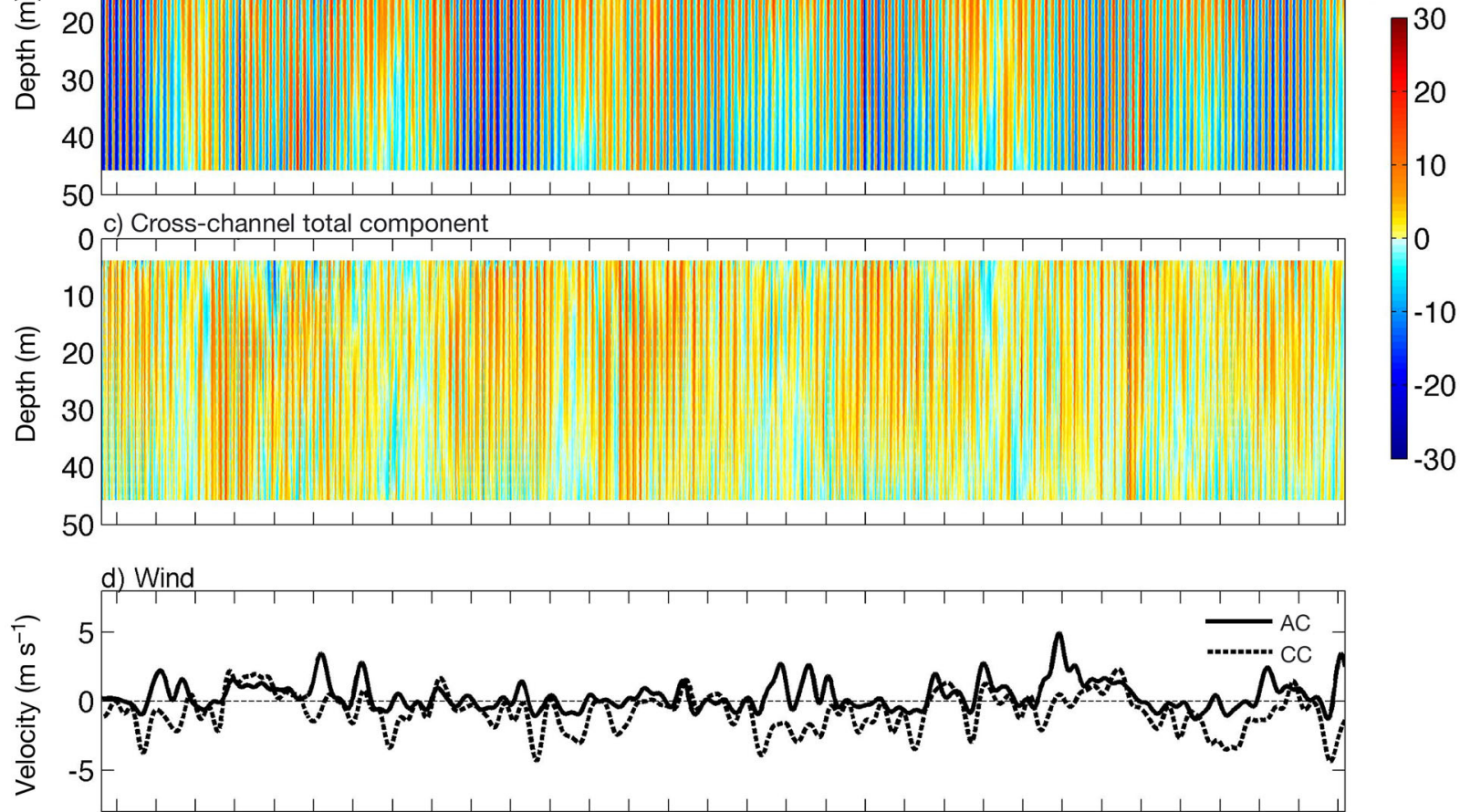

0 e) Along-channel residual component

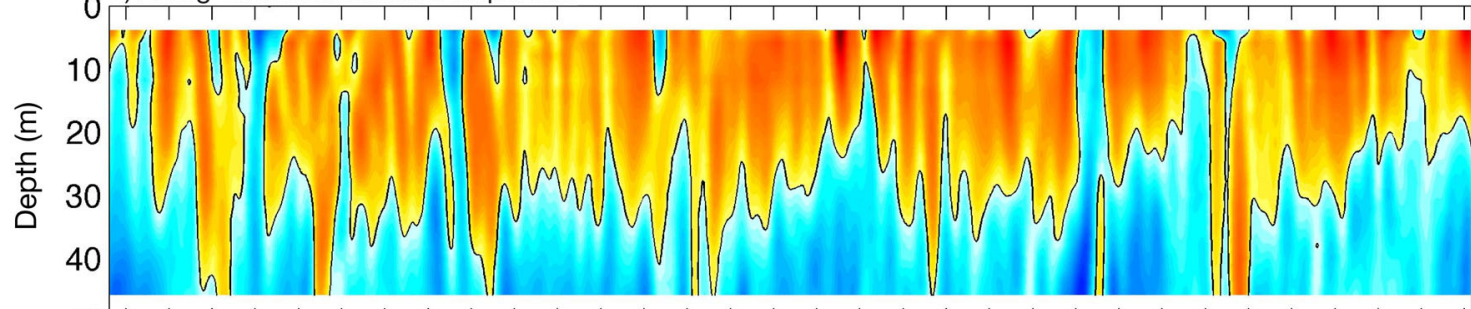

Velocity $\left(\mathrm{cm} \mathrm{s}^{-1}\right)$

$50 \frac{1}{f}+\frac{1}{f)}$ Cross-channel residual component
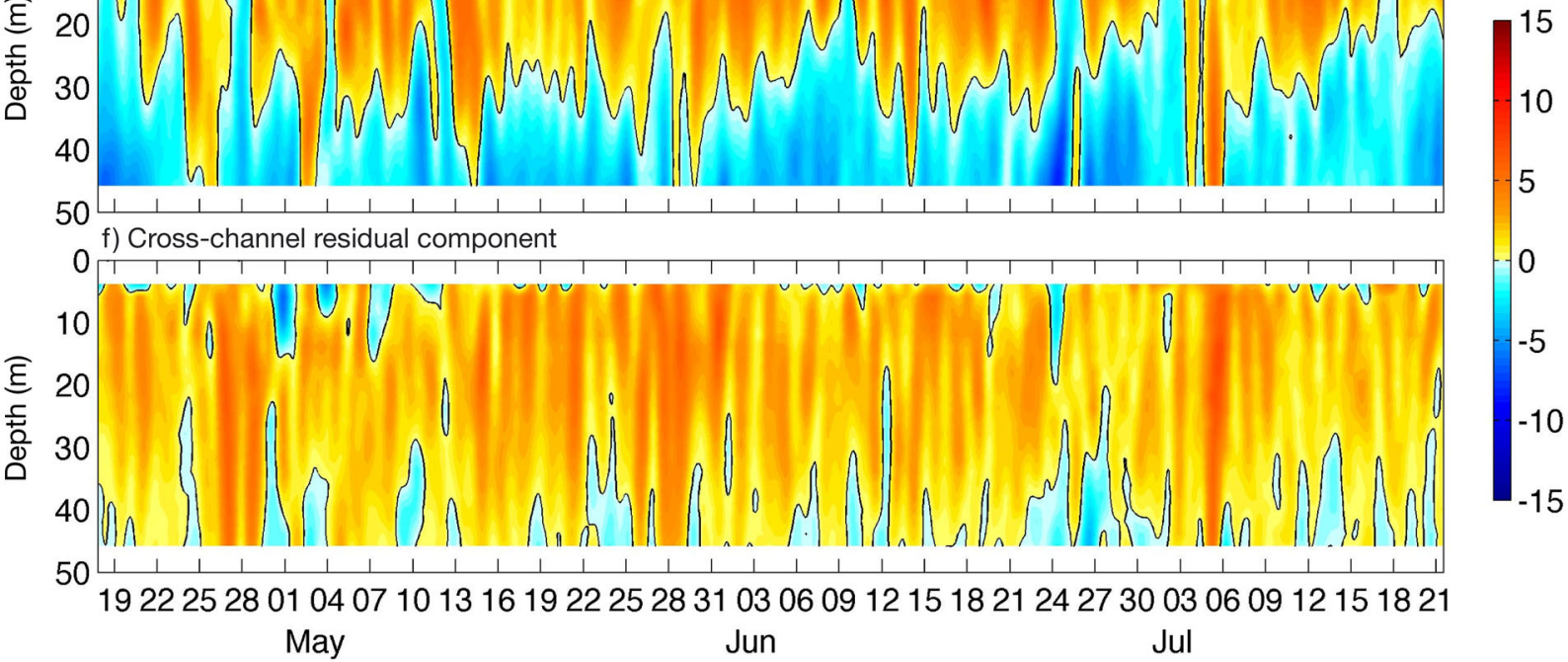

Fig. 7. (a) Sea level anomaly (SLA). (b,c) Cross- and along-channel component of the total currents. (d) Cross- (CC) and along-channel (AC) wind. (e,f) Cross- and along-channel residual currents. Data for 19 May and 21 July 2011 
Table 2. Residual distances, velocities, directions and stability coming from progressive vector diagrams during 6 neap tide periods. T: total currents and F: filtered currents. Each of these periods spans $3 \mathrm{~d}$ starting on the date shown. Each cell includes surface (upper), midwater (center) and bottom (lower) currents. -: not applicable

\begin{tabular}{|c|c|c|c|c|c|c|c|c|}
\hline & \multicolumn{2}{|c|}{$\begin{array}{l}\text { Distance } \\
(\mathrm{km})\end{array}$} & \multicolumn{2}{|c|}{$\begin{array}{l}\text { Velocity } \\
\left(\mathrm{km} \mathrm{d}^{-1}\right)\end{array}$} & \multicolumn{2}{|c|}{$\begin{array}{c}\text { Direction } \\
\left(^{\circ}\right)\end{array}$} & \multicolumn{2}{|c|}{$\begin{array}{c}\text { Stability } \\
(\%)\end{array}$} \\
\hline & $\mathrm{T}$ & $\mathrm{F}$ & $\mathrm{T}$ & $\mathrm{F}$ & $\mathrm{T}$ & $\mathrm{F}$ & $\mathrm{T}$ & $\mathrm{F}$ \\
\hline $\begin{array}{l}\text { Neap tides } \\
25 \text { April }\end{array}$ & $\begin{array}{l}8.8 \\
9.4 \\
6.8\end{array}$ & $\begin{array}{l}5.7 \\
8.4 \\
6.1\end{array}$ & $\begin{array}{l}3.0 \\
3.2 \\
2.3\end{array}$ & $\begin{array}{l}2.0 \\
2.9 \\
2.1\end{array}$ & $\begin{array}{c}63 \\
21 \\
4\end{array}$ & $\begin{array}{c}21 \\
6 \\
335\end{array}$ & $\begin{array}{l}47 \\
51 \\
41\end{array}$ & $\begin{array}{l}70 \\
89 \\
80\end{array}$ \\
\hline 10 May & $\begin{array}{l}6.7 \\
1.4 \\
6.0\end{array}$ & $\begin{array}{l}1.2 \\
4.5 \\
8.4\end{array}$ & $\begin{array}{l}2.2 \\
0.5 \\
2.0\end{array}$ & $\begin{array}{l}0.4 \\
1.5 \\
2.9\end{array}$ & $\begin{array}{l}113 \\
264 \\
280\end{array}$ & $\begin{array}{l}161 \\
310 \\
274\end{array}$ & $\begin{array}{l}35 \\
12 \\
56\end{array}$ & $\begin{array}{l}11 \\
74 \\
99\end{array}$ \\
\hline 25 May & $\begin{array}{c}12.6 \\
11.2 \\
4.5\end{array}$ & $\begin{array}{l}8.4 \\
8.2 \\
6.7\end{array}$ & $\begin{array}{l}4.3 \\
3.8 \\
1.5\end{array}$ & $\begin{array}{l}2.9 \\
2.8 \\
2.3\end{array}$ & $\begin{array}{l}62 \\
35 \\
34\end{array}$ & $\begin{array}{c}35 \\
7 \\
290\end{array}$ & $\begin{array}{l}63 \\
62 \\
34\end{array}$ & $\begin{array}{l}68 \\
95 \\
88\end{array}$ \\
\hline 10 June & $\begin{array}{c}21.3 \\
3.1 \\
8.7\end{array}$ & $\begin{array}{c}17.6 \\
4.1 \\
7.8\end{array}$ & $\begin{array}{l}7.2 \\
1.0 \\
2.9\end{array}$ & $\begin{array}{l}5.9 \\
1.4 \\
2.6\end{array}$ & $\begin{array}{c}94 \\
28 \\
257\end{array}$ & $\begin{array}{c}90 \\
23 \\
264\end{array}$ & $\begin{array}{l}76 \\
21 \\
60\end{array}$ & $\begin{array}{l}99 \\
66 \\
97\end{array}$ \\
\hline 25 June & $\begin{array}{c}10.6 \\
7.2 \\
1.0\end{array}$ & $\begin{array}{l}7.6 \\
2.8 \\
9.3\end{array}$ & $\begin{array}{l}3.6 \\
2.4 \\
0.3\end{array}$ & $\begin{array}{l}2.6 \\
0.9 \\
3.2\end{array}$ & $\begin{array}{c}78 \\
61 \\
225\end{array}$ & $\begin{array}{c}64 \\
329 \\
250\end{array}$ & $\begin{array}{l}75 \\
57 \\
10\end{array}$ & $\begin{array}{l}64 \\
69 \\
90\end{array}$ \\
\hline 10 July & $\begin{array}{c}20.4 \\
3.5 \\
6.0\end{array}$ & $\begin{array}{c}16.4 \\
4.2 \\
4.3\end{array}$ & $\begin{array}{l}6.9 \\
1.2 \\
2.0\end{array}$ & $\begin{array}{l}5.6 \\
1.4 \\
1.5\end{array}$ & $\begin{array}{c}95 \\
50 \\
255\end{array}$ & $\begin{array}{c}91 \\
54 \\
270\end{array}$ & $\begin{array}{l}84 \\
25 \\
42\end{array}$ & $\begin{array}{l}97 \\
99 \\
91\end{array}$ \\
\hline Mean & $\begin{array}{c}13.4 \\
6.0 \\
5.5\end{array}$ & $\begin{array}{l}9.5 \\
5.4 \\
7.1\end{array}$ & $\begin{array}{l}4.5 \\
2.0 \\
1.8\end{array}$ & $\begin{array}{l}3.2 \\
1.8 \\
2.4\end{array}$ & $\begin{array}{l}- \\
- \\
-\end{array}$ & $\begin{array}{l}- \\
- \\
-\end{array}$ & $\begin{array}{l}63 \\
38 \\
40\end{array}$ & $\begin{array}{l}68 \\
82 \\
91\end{array}$ \\
\hline $\begin{array}{l}\text { Standard } \\
\text { deviation }\end{array}$ & $\begin{array}{l}5.6 \\
3.6 \\
2.4\end{array}$ & $\begin{array}{l}5.8 \\
2.1 \\
1.6\end{array}$ & $\begin{array}{l}1.9 \\
1.2 \\
0.8\end{array}$ & $\begin{array}{l}1.9 \\
0.8 \\
0.6\end{array}$ & $\begin{array}{l}- \\
- \\
-\end{array}$ & $\begin{array}{l}- \\
- \\
-\end{array}$ & $\begin{array}{l}17 \\
19 \\
16\end{array}$ & $\begin{array}{c}29 \\
13 \\
6\end{array}$ \\
\hline
\end{tabular}

beginning of the current sampling period, the gradient Richardson number $\left(R_{i}\right)$ was lower than $0.5 \times 10^{-3}$, indicating a channel of low stratification compared to the flow turbulence. $R_{i}$ is a measure of the potential for instability of a sheared, stratified fluid. This is a dimensionless number defined as the square of the ratio of the buoyancy frequency, $N$, to the vertical shear (this latter quantity also having the dimensions of a frequency) (Apel 1987). Therefore, it is estimated that during this time of year (autumn and early winter), the buoyant flow within the channel was of less importance.

\section{DISCUSSION}

Appropriate knowledge of the temporal variability of coastal flows on the scale of an aquaculture production center is an effective management tool to reduce potential detrimental impacts on the environment, to control outbreaks of infectious diseases by water transport and to improve the relationship with neighboring centers. This is relevant in Chile, which is the second largest

\section{Hydrography of the Caucahue Channel}

The energy of the tidal currents in this channel, coupled with the low contribution of inland waters and weak incoming solar radiation during this season of the year led to a vertically mixed water column, in terms of temperature, salinity and dissolved oxygen (Fig. 10). Water temperatures fluctuated around $0.5^{\circ} \mathrm{C}$ between 11.2 and $11.7^{\circ} \mathrm{C}$. Salinities fluctuated from 32.5 to 33.1 , with lower values over the northern arm of the Caucahue Channel. These values identify Modified Subantarctic Waters (with salinities between 31 and 33) due to mixing with freshwater, but do not reach the range of estuarine waters $(<31)$ (Sievers \& Silva 2006). This led to stratification values lower than 8 cycles $^{-1}$ along the channel (i.e. buoyancy frequency, Fig. 10e). In terms of oxygen and density, this channel showed oxygenated waters with values from 4 to $5 \mathrm{ml} \mathrm{l}^{-1}$ and a practically uniform density structure along the channel and its vertical axis. Using Station 5 (close to the ADCP), at the producer of salmon in the world (Buschmann \& Fortt 2005), affected for the first time by the ISAV in June 2007 at a center off Lemuy Island, about $60 \mathrm{~km}$ south of the Caucahue Channel (Godoy et al. 2008, Kibenge et al. 2009). In Norway, this virus was detected in 1984, probably introduced by infected salmon and fish waste (Ellis et al. 2005). Seawater may also be a major route for disease transmission (Vågsholm et al. 1994, Jarp \& Karlsen 1997). Proximity of a farm to an ISAV-infected farm, especially when the distance between them is less than $5 \mathrm{~km}$, was found to be among the greatest risk factors for the spread of the virus (Gustafson et al. 2007, Mardones et al. 2011). In 2013, $75 \%$ of Chile's salmon farming concessions were located in a territory of no more than $300 \mathrm{~km}^{2}$, with a minimum distance between farms of $2.27 \mathrm{~km}$ (Buschmann \& Fortt 2005, Campos 2013). This contrasts with the $1700 \mathrm{~km}^{2}$ used in Norway where the farms do not have the spatial density that exists in Chile (Iizuka \& Katz 2011). Other studies on epidemics in Chile identified clus- 
Table 3. Residual distances, velocities, directions and stability coming from progressive vector diagrams during 6 spring tide periods. T: total currents and F: filtered currents. Each of these periods spans $3 \mathrm{~d}$ starting on the date shown. Each cell includes surface (upper), midwater (center) and bottom (lower) currents. -: not applicable

\begin{tabular}{|c|c|c|c|c|c|c|c|c|}
\hline & \multicolumn{2}{|c|}{$\begin{array}{l}\text { Distance } \\
(\mathrm{km})\end{array}$} & \multicolumn{2}{|c|}{$\begin{array}{l}\text { Velocity } \\
\left(\mathrm{km} \mathrm{d}^{-1}\right)\end{array}$} & \multicolumn{2}{|c|}{$\begin{array}{c}\text { Direction } \\
\left({ }^{\circ}\right)\end{array}$} & \multicolumn{2}{|c|}{$\begin{array}{c}\text { Stability } \\
(\%)\end{array}$} \\
\hline & $\mathrm{T}$ & $\mathrm{F}$ & $\mathrm{T}$ & $\mathrm{F}$ & $\mathrm{T}$ & $\mathrm{F}$ & $\mathrm{T}$ & $\mathrm{F}$ \\
\hline \multicolumn{9}{|l|}{ Spring tides } \\
\hline \multirow[t]{3}{*}{02 May } & 3.1 & 8.6 & 1.0 & 2.9 & 105 & 103 & 12 & 73 \\
\hline & 9.1 & 6.0 & 3.1 & 2.0 & 50 & 45 & 42 & 84 \\
\hline & 2.1 & 0.5 & 0.7 & 0.2 & 61 & 357 & 9 & 11 \\
\hline \multirow[t]{3}{*}{16 May } & 3.0 & 3.5 & 1.0 & 1.2 & 332 & 62 & 11 & 64 \\
\hline & 8.8 & 6.3 & 3.0 & 2.1 & 331 & 8 & 28 & 98 \\
\hline & 16.7 & 9.4 & 5.7 & 3.2 & 265 & 275 & 56 & 98 \\
\hline \multirow[t]{3}{*}{ 02 June } & 7.5 & 11.0 & 2.5 & 3.7 & 48 & 68 & 38 & 99 \\
\hline & 6.3 & 6.5 & 2.1 & 2.2 & 34 & 28 & 31 & 93 \\
\hline & 9.0 & 9.4 & 3.0 & 3.2 & 278 & 278 & 49 & 99 \\
\hline \multirow[t]{3}{*}{16 June } & 2.3 & 8.2 & 0.8 & 2.8 & 83 & 95 & 10 & 91 \\
\hline & 7.7 & 6.4 & 2.6 & 2.2 & 335 & 31 & 34 & 98 \\
\hline & 13.5 & 6.3 & 4.6 & 2.1 & 264 & 272 & 63 & 99 \\
\hline \multirow[t]{3}{*}{ 02 July } & 10.1 & 6.5 & 3.4 & 2.2 & 308 & 333 & 43 & 72 \\
\hline & 4.2 & 5.1 & 1.4 & 1.7 & 330 & 350 & 18 & 77 \\
\hline & 3.7 & 2.9 & 1.2 & 1.0 & 279 & 304 & 18 & 72 \\
\hline \multirow[t]{3}{*}{16 July } & 8.0 & 8.5 & 2.7 & 2.9 & 350 & 38 & 30 & 74 \\
\hline & 9.0 & 3.9 & 3.0 & 1.3 & 308 & 324 & 37 & 93 \\
\hline & 10.3 & 5.1 & 3.5 & 1.7 & 275 & 271 & 47 & 94 \\
\hline \multirow[t]{3}{*}{ Mean } & 5.7 & 7.7 & 1.9 & 2.6 & - & - & 24 & 79 \\
\hline & 7.5 & 5.7 & 2.5 & 1.9 & - & - & 32 & 91 \\
\hline & 10.3 & 5.6 & 3.1 & 1.9 & - & - & 40 & 79 \\
\hline \multirow{3}{*}{$\begin{array}{l}\text { Standard } \\
\text { deviation }\end{array}$} & 3.3 & 2.5 & 1.1 & 0.8 & - & - & 15 & 13 \\
\hline & 1.9 & 1.0 & 0.7 & 0.4 & - & - & 8 & 8 \\
\hline & 5.6 & 3.5 & 1.9 & 1.2 & - & - & 22 & 35 \\
\hline
\end{tabular}

tering of ISAV-infected farms within a $15 \mathrm{~km}$ radius (Mardones et al. 2009). Similarly, adjacent farms within a seaway distance $<10 \mathrm{~km}$ in Norway (Lyngstad et al. 2008) and $<7 \mathrm{~km}$ in the epidemic in Scotland (Murray et al. 2005) have been epidemiologically linked. Considering these spatial scales, the Caucahue Channel with its 2 north and south arms of 7 and $11 \mathrm{~km}$, respectively, would be within these limits of epidemiological dispersion. However, according to Mardones et al. (2011), of all salmon farms present in this channel, ISAV affected only those in the southern arm. This is consistent with the southward surface residual flow and the Quemchi constriction described in this work.

In this context, the design and distribution of aquaculture production centers within any coastal marine basin will depend critically on: (1) the physical scales like $L_{\mathrm{adv}}$ and $L_{\text {exci }}(2)$ the scales of distances between centers $\left(L_{\text {int }}\right)$ and size of centers $\left(L_{\text {cen }}\right)$; and (3) the degree of dispersal of propagules of marine organisms $\left(L_{\text {diff }}\right)$. Largier (2003) applied the concepts of $L_{\mathrm{adv}}$ and $L_{\text {diff }}$ for estimating larval dispersal distances related with marine protected areas. The values found for the Caucahue Channel were $L_{\mathrm{adv}}=5.4$ to $9.6 \mathrm{~km}$ and $L_{\text {exc }}=1.2$ to $4 \mathrm{~km}$. Major values of $L_{\text {exc }}$ predominated in surface layers and occurred during spring tides. $L_{\text {cen }}$ fluctuated between 0.1 and $0.3 \mathrm{~km}$, and $L_{\text {int }}$ was more variable, ranging from 1 to $5 \mathrm{~km}$, if only salmon culture is considered, or less, if all production centers are considered. It is expected that well-distributed centers meet the condition of $L_{\text {exc }}<L_{\text {inti }} L_{\text {diff }}<L_{\text {inti }}$ and $L_{\text {int }}>$ $\left(L_{\mathrm{adv}}-L_{\text {exc }}\right)$. In this way, the centers do not share the same water column twice a day with the semidiurnal tidal excursion and neither the scale of biological dispersion will reach neighboring centers. $L_{\text {diff }} \approx\left(K T_{\text {diff }}\right)^{1 / 2}$ and cannot be evaluated in this investigation because it depends on the local dispersion coefficient $(K)$ (eddy diffusivity) for pathogens of interest for aquaculture. Here, $T_{\text {diff }}$ are the aggregation times in obtaining $K$ values (Largier, 2003). Using a weak diffusion $\left(K<100 \mathrm{~m}^{2} \mathrm{~s}^{-1}\right)$ and $T_{\text {diff }}=3 \mathrm{~d}$, the dispersive scales reach $5 \mathrm{~km}$, approximately.

In this way, short-range connectivity occurs when $L_{\text {adv }} / L_{\text {diff }}<<1$ and $L_{\text {adv }} / L_{\text {exc }}<<1$. In this case, the diffusive and oscillatory flow scales will be strong and pathogens will tend to remain for longer in the vicinity of the centers. In the case of the Caucahue Channel, $L_{\text {adv }} / L_{\text {exc }}$ fluctuated between 1.3 and 8, approximately. Although $L_{\mathrm{adv}}$ is greater than $L_{\mathrm{exc}}$ this value is rather close to 1 , which implies that this channel is dominated by the tidal oscillatory flows most of the time. This added to the fact that the length of its southern $\operatorname{arm}(L=11 \mathrm{~km})$ is greater than $L_{\mathrm{adv}}, L_{\mathrm{exc}}$ and $L_{\text {diff, }}$ implying that the channel would tend to retain pathogens, at temporary life scales of $3 \mathrm{~d}$.

On the other hand, a long-range connectivity will occur when $L_{\text {adv }} / L_{\text {diff }} \gg 1$ and $L_{\text {adv }} / L_{\text {exc }} \gg 1$. In this case, the diffusive and oscillatory flow scales will be weak and the mean advective flow will dominate the export of material from a local center (the channel will behave like a river). In the case of the Caucahue Channel, $L_{\text {adv }}$ is not vertically homogeneous. The surface layer will affect the centers located east of the 

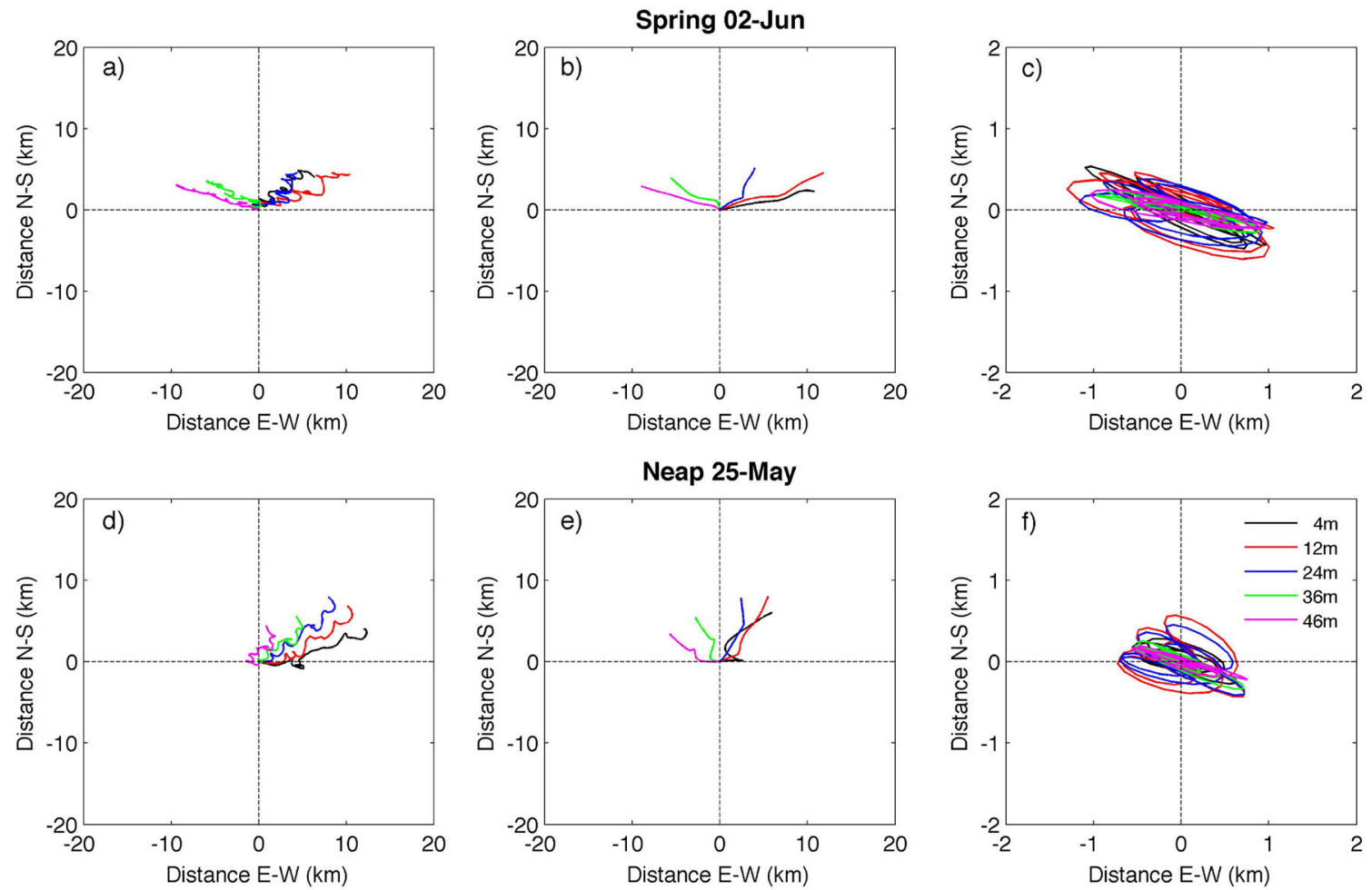

Fig. 8. Progressive vector diagrams constructed using $3 \mathrm{~d}$ of $(\mathrm{a}, \mathrm{d})$ total currents, $(\mathrm{b}, \mathrm{e})$ residual currents and (c,f) tidal currents: $(\mathrm{a}-\mathrm{c})$ during spring tides, beginning on 2 June 2011 and (d-f) during neap tides, beginning on 25 May 2011. Colors indicate the depth of measurements of the currents

ADCP location, while the bottom layer will be advected westward.

In all of these cases of greater or lesser proximity between aquaculture production centers, the physical and biological mechanisms involved in the connectivity among them can be summarized as: tidal excursion, residual advection, turbulence and biological diffusive scales (Largier 2003, Murray et al. 2005). In general, $L_{\text {exc }}$ (circular or elliptical) has received increasing attention related to management policies on farms (Chang et al. 2005b, Page et al. 2005, Campos 2013, Cornejo et al. 2014). However, $L_{\text {adv }}$ may be as or more important than $L_{\text {exc }}$. Everything will depend on the time scale used and the structure of the residual flow. In the case of the Caucahue Channel, it is not easy to determine the origin of this flow considering the topographic complexity of this channel and that the currents were measured at only 1 point. Xuan et al. (2016) pointed out that the residual flow can be separated in 2 components: first, a non-tidal residual current induced by non-tidal residual forcing, such as wind stress, buoyancy forcing and/or external flow at the open boundary, and second, a tidal residual current induced by non-linear effects of oscillatory tidal currents with bottom topography. As we have shown in this work, the input of buoyancy and the wind influence were not the essential factors that explained the residual flow. In addition, the residual flow was more important in the cross-channel component ( $60 \%$ of the variance of the total currents) than in the along-channel component (only $20 \%$ ). This intense cross-channel residual current was consistent with the northward trajectories (shown in Fig. 8b,e). The origin of this particular pattern of the residual trajectories is not easy to determine and goes beyond the objectives of this work. However, the following can be hypothesized. It is expected that, due to the low depth at the Quemchi constriction and the reduction of the cross-sectional area in this sector (compared to the rest of the channel), the ebb tides (eastwards) will be faster than the flood (westward). Due to friction with the bottom, it is also expected that the ebb tides will have more velocity in the surface layer than in the bottom layer. This is observable in Fig. 2, which shows, on the surface layer, higher ebb speeds than floods tides. This funnel effect in the Quemchi constriction will modify the duration of effective ebb and flood tides. This can be demonstrated by calculating the tidal asymmetry index described by Mantovanelli et al. (2004) and defined as: $\mathrm{AI}_{\mathrm{DV}}=A_{\mathrm{D}}+A_{\mathrm{V}}$, which considers the 

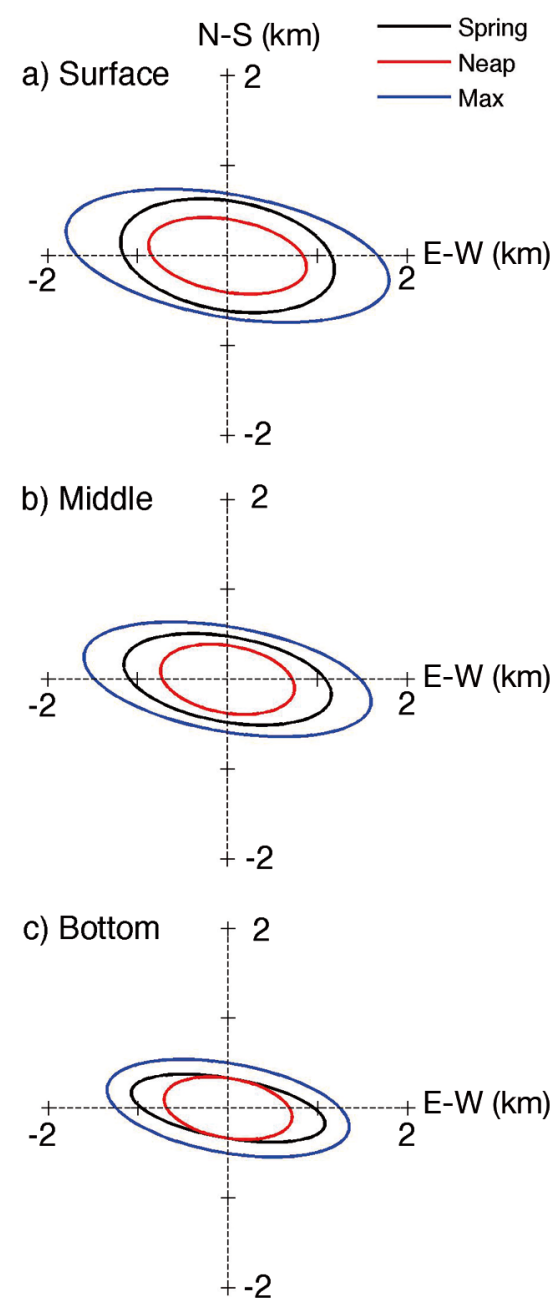

Fig. 9. Semidiurnal tidal excursions $\left(D_{X}\right.$ and $\left.D_{y}\right)$ at (a) the surface, (b) midwater and (c) bottom. In each panel, the black and red ellipses correspond to an average of the semidiurnal tidal currents during spring tides and neap tides, respectively. The blue ellipses indicate the tidal excursions calculated with the maximum semidiurnal currents. The horizontal axis is oriented in the east-west direction

combined effect of the tidal asymmetries in duration $\left(A_{\mathrm{D}}\right)$ and in mean velocity $\left(A_{\mathrm{V}}\right)$ between the ebb and flood period (along-channel flows). The $A_{\mathrm{D}}$ and $A_{\mathrm{V}}$ parameters are described by:

$$
A_{\mathrm{D}}=\left(\frac{t_{e}-t_{f}}{t_{e}+t_{f}}\right), A_{\mathrm{V}}=\left(\frac{\bar{u}_{e}-\left|\bar{u}_{f}\right|}{\bar{u}_{e}+\left|\bar{u}_{f}\right|}\right)
$$

where $t_{\mathrm{e}}$ and $t_{\mathrm{f}}$ are the duration of the ebb and flood tides, respectively, computed based on the direction of the tidal currents (sign of the currents during ebb and flood). $\bar{u}_{e}$ and $\bar{u}_{f}$ correspond to the average velocity during each ebb and flood, respectively. Positive and negative $\mathrm{AI}_{\mathrm{DV}}$ values indicate the domain of the ebb and flood tides, respectively. The $\mathrm{AI}_{\mathrm{DV}}$ index was applied for each depth level and using along- and cross-channel tidal currents (Fig. 11). The $\mathrm{AI}_{\mathrm{DV}}$ varied with the spring-neap cycle (Fig. 11a). During spring tides, the ebb currents, excepting bottom currents, dominated the along-channel flow due to the accelerated flow in the Quemchi constriction (Fig. 11b). During neap tides, the along-channel flow was dominated by flood tides. In the cross-channel component, the $\mathrm{AI}_{\mathrm{DV}}$ was vertically more homogeneous, favoring the southward and northward currents, during spring and neap tides, respectively. The northward residual flow therefore comes from the positive predominance of the $\mathrm{AI}_{\mathrm{DV}}$ in the cross-channel component, especially during neap tides (Fig. 11c).

Unlike $L_{\text {exc }} L_{\text {adv }}$ will grow rapidly with the increase in the pathogen survival rate in the water column. In the particular case of ISAV, Falk et al. (1997) reported that the virus remains infectious for $14 \mathrm{~d}$ at $4^{\circ} \mathrm{C}$ and for $10 \mathrm{~d}$ at $15^{\circ} \mathrm{C}$ in cell culture supernatant, while others showed different values (Nylund et al. 1994, Rimstad \& Mjaaland 2002). The virus could survive for extended periods in freshwater at low temperature; however, the survival of ISAV was greatly decreased in seawater independently of the water temperature (Tapia et al. 2013). Tapia et al. (2013) also showed that salinity would be the most restrictive variable with a survival probability of $50 \%$ for times between 8 and $30 \mathrm{~d}$. Considering just $8 \mathrm{~d}, L_{\text {adv }}$ will be greater than the length of the southern arm of the Caucahue Channel, which would allow arguing that a pathogen such as ISAV located at the surface layer could be advected out of the channel through the south mouth. In the case of the spread of infectious larval sea lice Lepeophtheirus salmonis, the lifespan of the planktonic stages can last approximately $14 \mathrm{~d}$ at $10^{\circ} \mathrm{C}$, and significant transport and dispersion within surface currents are possible (Johnson \& Albright 1991, Amundrud \& Murray 2009).

Considering the regions affected by the crisis of ISAV in southern Chile in 2007-2009 (Mardones et al. 2011), it is very difficult to explain its dispersion pattern solely based on hydrodynamic bases (see Fig. 1, from Mardones et al. 2011). The extent of the epidemic in the 3 phases described by these authors (initial spread, epidemic growth and stasis) during 150 wk (covering the 10th and 11th Regions of Chile) requires more additional information. Even the concept of internal borders (Forrest et al. 2009) is very difficult to apply in this case. The ISAV spread overcame several internal borders that could be considered natural (freshwater fronts, the oceanographic barrier imposed by the Corcovado Gulf, multiple geographical barriers imposed by the shape of channels and fjords, etc.). 

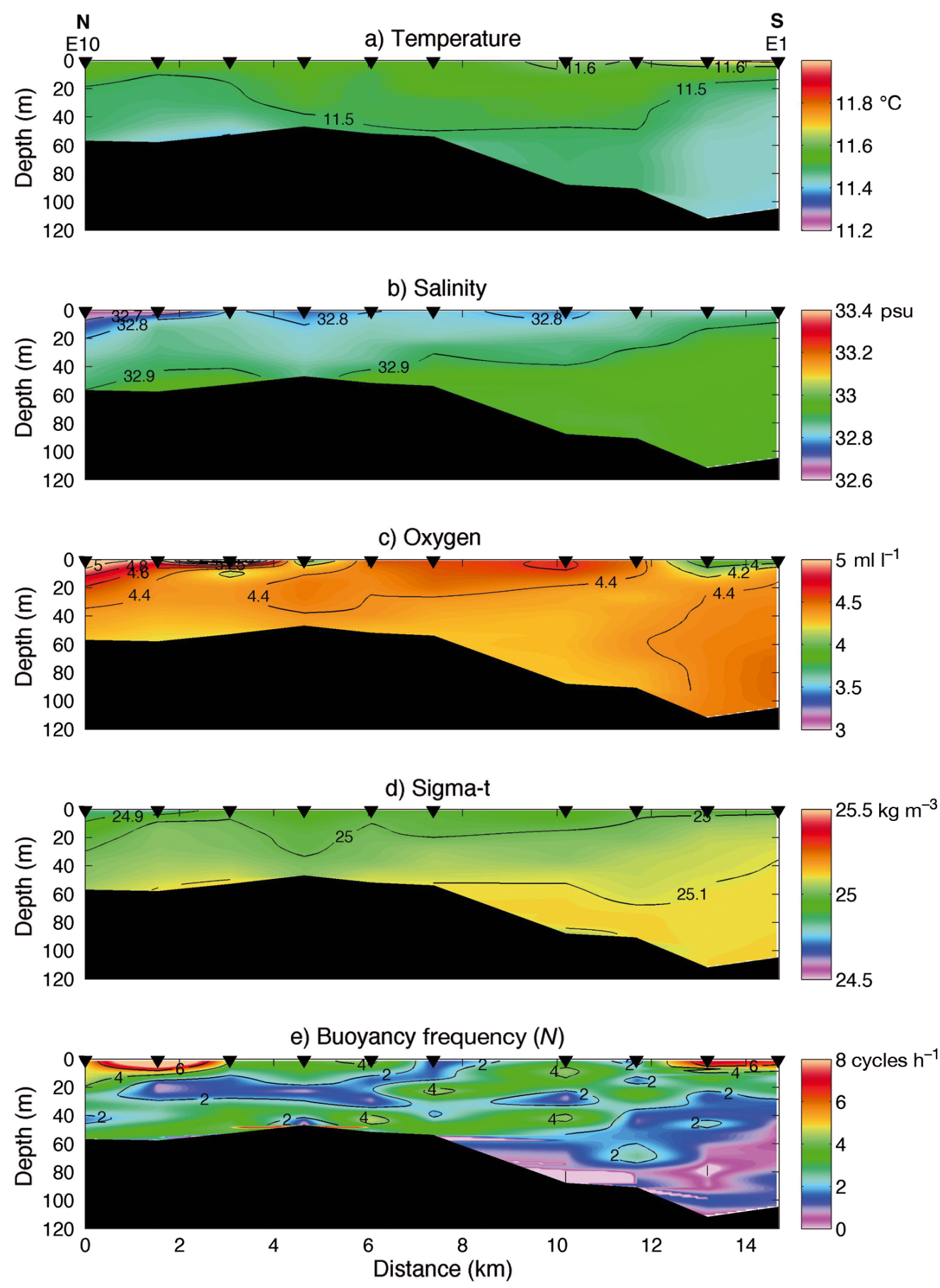

Fig. 10. Hydrographic section along the Caucahue Channel, 17-19 April 2011. The horizontal axis (distance in km) has its origin at Station 10, located in the north arm of the channel. Black triangles on the upper horizontal axis indicate the location of the hydrographic stations

Therefore, the decision for the location of a new aquaculture center in relation to other existing centers is a matter that must be carefully evaluated and will depend on the tidal excursion, residual transport and biological diffusive scales. A better understanding of the connectivity mechanisms between aquaculture production centers will require a greater knowledge of the local $L_{\text {adv }}$ and $L_{\text {exc }}$ scales and biological dispersal scales $\left(L_{\text {diff }}\right)$. Also, the dispersion of longer-lived pathogens will be better modeled using a more sophisticated advection-diffusion model (Largier 2003, Murray et al. 2005). 

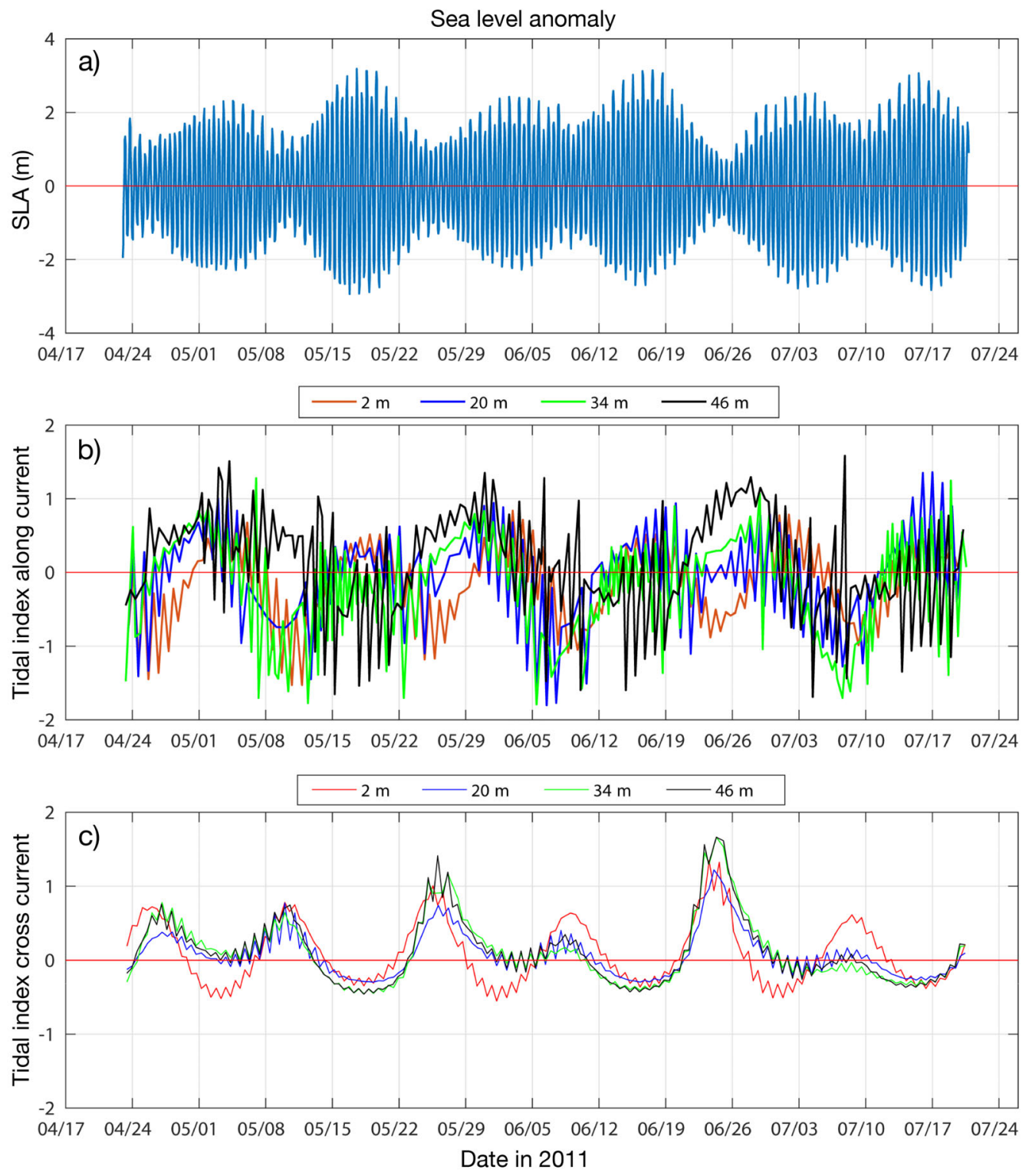

Fig. 11. (a) Sea level anomaly (SLA, in $\mathrm{m})$. (b) Tidal asymmetry index ( $\mathrm{AI}_{\mathrm{DV}}$ ) calculated using along-channel currents. (c) $\mathrm{AI}_{\mathrm{DV}}$ calculated using cross-channel currents. This index (dimensionless) was calculated using currents measured at 2, 20, 34 and 46 m depth. Caucahue Channel, 17 April to 24 July 2011

\section{CONCLUSIONS}

The mean flow of the total current located near to the center of Caucahue Channel showed 2 layers (eastward at the surface and westward at the bottom) with speeds that did not exceed $30 \mathrm{~cm} \mathrm{~s}^{-1}$. Alongchannel tidal currents behaved, approximately, as a standing wave, explaining around $80 \%$ of the total variance. In contrast, the cross-channel tidal currents explained between 40 and $60 \%$ of the total variance.

The input of buoyancy and the wind influence were not the essential factors that explained the high cross-channel residual flow. We propose that this flow was generated by tidal asymmetry as a result of the oscillating tidal flow passing through the Quemchi constriction. This hypothesis should be evaluated with new studies that incorporate more observations of currents and high-resolution numerical models.

For $3 \mathrm{~d}$ time scales, the $L_{\mathrm{adv}} / \mathrm{L}_{\text {exc }}$ ratio fluctuated between 1.3 and 8, approximately, implying that this channel is dominated by tidal oscillatory flows most of the time. Additionally, as the length of the south arm of this channel $(L=11 \mathrm{~km})$ is greater than $L_{\mathrm{adv}}$, $L_{\text {exc }}$ and $L_{\text {diff, }}$ pathogens will tend to be retained in 
this channel. For longer-lived pathogens (e.g. greater than $15 \mathrm{~d}$ ), this ratio will grow 1 order of magnitude, which means that, in case of an internal outbreak, the Caucahue Channel may become a source of pathogens for the CIS.

Residual circulation coming from non-linear effects of tidal currents with bottom topography must be considered in the study of connectivity patterns between aquaculture production centers.

Acknowledgements. We thank José Aguilar, captain of the vessel 'Don Jose', who collaborated on fieldwork related to the installation and retrieval of oceanographic instruments in the Caucahue Channel (Chiloe Island). M.S. was partially supported by INCAR (FONDAP-CONICYT No. 15110027), and L.B. acknowledges support from the Chilean Millennium Initiative NC120030 and CONICYT-PAI/ National Competition Insertion in the Academy, Call 2016 No. 79160044. The INNOVA-CORFO project No. 09MCSS-6673 provided the ADCP and CTDO data.

\section{LITERATURE CITED}

Aiken CM (2008) Barotropic tides of the Chilean Inland Sea and their sensitivity to basin geometry. J Geophys Res 113:C08024

Amundrud TL, Murray AG (2009) Modelling sea lice dispersion under varying environmental forcing in a Scottish sea loch. J Fish Dis 32:27-44

Apel JR (1987) Principles of ocean physics. International Geophysics Series Vol 38. Academic Press, San Diego, CA

Brooks DA (2004) Modeling tidal circulation and exchange in Cobscook Bay, Maine. Northeast Nat 11(Spec Issue 2): 23-50

Buschmann A, Fortt A (2005) Efectos ambientales de la acuicultura intensiva y alternativas para un desarrollo sustentable. Rev Ambiente Desarro 21:58-64

Buschmann A, Troell M, Kautsky N (2001) Integrated algal farming: a review. Cah Biol Mar 42:83-90

Buschmann A, Riquelme V, Hernández-González M, Varela $\mathrm{D}$ and others (2006) A review of the impacts of salmonid farming on marine coastal ecosystems in the southeast Pacific. ICES J Mar Sci 63:1338-1345

Buschmann A, Cabello F, Young K, Carvajal J and others (2009) Salmon aquaculture and coastal ecosystem health in Chile: analysis of regulations, environmental impacts and bioremediation systems. Ocean Coast Manag 52: 243-249

Buschmann A, Olivares G, Dempster P, Valerio V, Godoy M (2013) Modelo de dispersion del virus ISA (ISAv) basado en simulación numérica del océano y la atmósfera: alcances y desafíos. In: Santelices B, Lund F, Cooper T, Asenjo $\mathrm{J}$ (eds) Innovación basada en el conocimiento científico. Academia Chilena de Ciencias, Santiago, p 15-32

Bustos B (2012) Brote del virus ISA: crisis ambiental y capacidad de la institucionalidad ambiental para manejar el conflicto. EURE 38:219-245

Cáceres M, Valle-Levinson A, Atkinson L (2003) Observations of cross-channel structure of flow in an energetic tidal channel. J Geophys Res 108:3114
Cáceres M, Valle-Levinson A, Bello M (2008) Residual flow over a bump in Quellón Bay. Rev Biol Mar Oceanogr 43: 629-639

Campos P (2013) Evaluación de las agrupaciones de concesiones de acuicultura implementadas en la industria del cultivo del salmón en Chile en base a zonas estimadas por modelos de trayectoria de partículas. $\mathrm{PhD}$ thesis, Universidad Católica del Norte, Pontificia Universidad Católica de Valparaíso and Universidad de Chile

* Castillo M, Pizarro O, Cifuentes U, Ramirez N, Djurfeldt L (2012) Subtidal dynamics in a deep fjord of southern Chile. Cont Shelf Res 49:73-89

Chang BD, Page FH, Losier RJ, Greenberg DA and others (2005a) Water circulation and management of infectious salmon anemia in the salmon culture industry of Cobscook Bay, Maine and adjacent southwestern New Brunswick. Can Tech Rep Fish Aquat Sci 2598

Chang BD, Page FH, Losier RJ, Greenberg DA and others (2005b) Application of a tidal circulation model for fish health management of salmon farms in the Grand Manan Island area, Bay of Fundy. In: Waddy S (ed) Proceedings of the Fourth St. Andrews Aquaculture Workshop 'Water movement and aquatic animal health', 21-22 November 2005, St. Andrews, Canada. Bull Aquacult Assoc Can 105-1:22-33

Cornejo P, Sepúlveda H, Gutiérrez M, Olivares G (2014) Numerical studies on the hydrodynamic effects of a salmon farm in an idealized environment. Aquaculture 430:195-206

Ellis S, Gustafson L, Giray C, Robinson T and others (2005) Hydrographics and the epidemiology of ISA: findings from a high-risk region in Maine and New Brunswick. In: Waddy S (ed) Proceedings of the Fourth St. Andrews Aquaculture Workshop 'Water movement and aquatic animal health', 21-22 November 2005, St. Andrews, Canada. Bull Aquacult Assoc Can 105-1:44-51

Falk K, Namork E, Rimstad E, Mjaaland S, Dannevig BH (1997) Characterization of infectious salmon anemia virus, an orthomyxo-like virus isolated from Atlantic salmon (Salmo salar L.). J Virol 71:9016-9023

Forrest BM, Gardner JPA, Taylor MD (2009) Internal borders for managing invasive marine species. J Appl Ecol 46:46-54

Godoy MG, Aedo A, Kibenge MJ, Groman DB and others (2008) First detection, isolation and molecular characterization of infectious salmon anaemia virus associated with clinical disease in farmed Atlantic salmon (Salmo salar) in Chile. BMC Vet Res 4:28

Gustafson LL, Ellis SK, Beattie MJ, Chang BD and others (2007) Hydrographics and the timing of infectious salmon anemia outbreaks among Atlantic salmon (Salmo salar L.) farms in the Quoddy region of Maine, USA and New Brunswick, Canada. Prev Vet Med 78:35-56

Iizuka M, Katz J (2011) Natural resources industries, 'tragedy of the commons' and the case of Chilean salmon farming. Int J Inst Econ 3:259-286

Jarp J, Karlsen E (1997) Infectious salmon anaemia (ISA) risk factors in sea-cultured Atlantic salmon Salmo salar. Dis Aquat Org 28:79-86

Johnson SC, Albright LJ (1991) Development, growth, and survival of Leopeophtheirus salmonis (Copepoda: Caligidae) under laboratory conditions. J Mar Biol Assoc UK 71:425-463

Kibenge FS, Godoy MG, Wang Y, Kibenge MJ and others (2009) Infectious salmon anaemia virus (ISAV) isolated 
from the ISA disease outbreaks in Chile diverged from ISAV isolates from Norway around 1996 and was disseminated around 2005, based on surface glycoprotein gene sequences. Virol J 6:88

Largier JL (2003) Considerations in estimating larval dispersal distances from oceanographic data. Ecol Appl 13(Suppl):S71-S89

Lyngstad TM, Jansen PA, Sindre H, Jonassen CM, Hjortaas MJ, Johnsen S, Brun E (2008) Epidemiological investigation of infectious salmon anaemia (ISA) outbreaks in Norway 2003-2005. Prev Vet Med 84:213-227

Mantovanelli A, Marone E, da Silva ET, Lautert LF and others (2004) Combined tidal velocity and duration asymmetries as a determinant of water transport and residual flow in Paranaguá Bay estuary. Estuar Coast Shelf Sci 59:523-537

Mardones FO, Perez AM, Carpenter TE (2009) Epidemiologic investigation of the re-emergence of infectious salmon anemia virus in Chile. Dis Aquat Org 84:105-114

Mardones FO, Pérez AM, Valdes-Donoso P, Carpenter TE (2011) Farm level reproduction number during an epidemic of infectious salmon anemia virus in southern Chile in 2007-2009. Prev Vet Med 102:175-184

Marín V, Campuzano F (2008) Un modelo hidrodinámico barotrópico para los fiordos australes de Chile entre los $41^{\circ} \mathrm{S}$ y los $46^{\circ} \mathrm{S}$. Cienc Tecnol Mar 31:125-136

Murray A, Amundrud TL, Gillibrand PA (2005) Models of hydrodynamic pathogen dispersal affecting Scottish salmon production: modelling shows how Scotland eradicated ISA, but not IPN. In: Waddy S (ed) Proceedings of the Fourth St. Andrews Aquaculture Workshop 'Water movement and aquatic animal health', 21-22 November 2005, St. Andrews, Canada. Bull Aquacult Assoc Can 105-1:79-86

Nylund A, Hovland T, Hodneland K, Nilsen F, Løvik P (1994) Mechanisms for transmission of infectious salmon anemia (ISA). Dis Aquat Org 19:95-100

Page FH, Chang BD, Losier RJ, Greenberg DA and others (2005) Water circulation and management of infectious salmon anemia in the salmon aquaculture industry of southern Grand Manan Island, Bay of Fundy. Can Tech Rep Fish Aquat Sci 2595

Pawlowicz R, Beardsley B, Lentz S (2002) Classical tidal harmonic analysis including error estimates in MATLAB using T_TIDE. Comput Geosci 28:929-937

Pond S, Pickard G (1983) Introductory dynamical oceanog-

Editorial responsibility: Craig Stevens,

Wellington, New Zealand raphy. Elsevier Butterworth-Heinemann, Oxford, MA

* Rimstad E, Mjaaland S (2002) Infectious salmon anaemia virus: an orthomyxovirus causing an emerging infection in Atlantic salmon. APMIS 110:273-282

Rudolph A, Medina P, Novoa V, Ahumada R, Cortés I (2010) Calidad ecotoxicológica de sedimentos en sectores del mar interior de Chiloé, campaña CIMAR 12 Fiordos. Cienc Tecnol Mar 33:17-29

Salinas S, Castillo M (2012) Caracterización de las corrientes mareales y submareales en canal Desertores $\left(42^{\circ} 42^{\prime} \mathrm{S}_{\text {; }}\right.$ $72^{\circ} 50^{\prime}$ W). Cienc Tecnol Mar 35:5-18

Sernapesca (2012) Anuario Estadístico de Pesca y Acuicultura. Gobierno de Chile, Valparaíso. www.sernapesca.cl/ informes/estadisticas/2012_series_2002_2012.xls

Sernapesca (2015) Anuario Estadístico de Pesca y Acuicultura. Gobierno de Chile, Valparaíso. www.sernapesca.cl/ informes/estadisticas/2015_series_2005_2015.xls

Sievers H, Silva N (2006) Masas de agua y circulación en los canales y fiordos australes. In: Silva N, Palma S (eds) Avances en el conocimiento oceanográfico de las aguas interiores chilenas. Puerto Montt a cabo de Hornos. Comité Oceanográfico Nacional, Servicio Hidrográfico y Oceanográfico de la Armada de Chile, Valparaiso, p 53-58

Tapia E, Monti G, Rozas M, Sandoval A, Gaete A, Robles H, Bustos P (2013) Assessment of the in vitro survival of the Infectious Salmon Anaemia Virus (ISAV) under different water types and temperature. Bull Eur Assoc Fish Pathol 33:3-12

*Vågsholm I, Djupvik H, Willumsen F, Tveit A, Tangen K (1994) Infectious salmon anaemia (ISA) epidemiology in Norway. Prev Vet Med 19:277-290

Valle-Levinson A (2013) Some basic hydrodynamic concepts to be considered for coastal aquaculture. In: Ross LG, Telfer TC, Falconer L, Soto D, Aguilar-Manjarrez J (eds) Site selection and carrying capacities for inland and coastal aquaculture. FAO/Institute of Aquaculture, University of Stirling, Expert Workshop, 6-8 December 2010. FAO Fisheries and Aquaculture Proceedings No. 21. FAO, Rome, p 147-158

* Valle-Levinson A, Cáceres M, Pizarro O (2014) Variations of tidally driven three-layer residual circulation in fjords. Ocean Dyn 64:459-469

Xuan J, Yang Z, Huang D, Wang T, Zhou F (2016) Tidal residual current and its role in the mean flow on the Changjiang Bank. J Mar Syst 154:66-81

Submitted: May 2, 2017; Accepted: March 14, 2018

Proofs received from author(s): June 6, 2018 